\title{
A vulnerabilidade da urbanização do centro sul do Brasil frente à va- riabilidade climática ${ }^{1}$.
}

\author{
Magaly Mendonça \\ Departamento de Geociências da UFSC, Florianópolis-SC, Brasil \\ magaly@cfh.ufsc.br
}

\begin{abstract}
RESUMO
Este trabalho teve por objetivo refletir sobre os desastres naturais pluviométricos ocorridos no Brasil, abordando não somente o fenômeno climático em si, mas, os fatores que em conjunto causam as catástrofes. A discussão em torno de mudanças climáticas tem subestimado a importância das variabilidades multidecadais que podem revolucionar a forma como fazemos a climatologia e planejamentos de longo prazo. A urbanização tem sido reconhecida como um dos principais componentes para que eventos climáticos tornem-se desastres naturais. Assim buscou-se também um pouco de sua evolução histórica no Rio de Janeiro, São Paulo e Florianópolis para contextualizar as condições de vulnerabilidade em que se encontra grande parte da população brasileira. De fato, o crescimento e a expansão urbana ocorrem sem a consideração das naturais restrições da superfície terrestre e da recorrência das variabilidades climáticas, aumentando a vulnerabilidade de grande parte da população.
\end{abstract}

Palavras-chave: inundação, urbanização, variabilidade climática, vulnerabilidades.

\section{Central southern brazil urbanization vulnerability and its relationship with climatic variability}

\begin{abstract}
The aim of this work is to review pluviometric natural disasters which have occurred in Brazil, addressing not only the climatic phenomenon, but also the joining factors that cause them. The discussion about climate change has underestimated the importance of multidecadal variability that could revolutionize the way that long term climatology and plans are done. Urbanization has been recognized as a key component for the transformation of weather events into natural disasters. Historical development of Rio de Janeiro, São Paulo and Florianopolis has been considered to contextualize vulnerability conditions in which a large part of the Brazilian population lives. In fact, urban growth and sprawl occur without consideration of natural constraints of land surfaces and climate variability, increasing the vulnerability of much of the population.
\end{abstract}

Key word: flooding, urbanization, climate variability, vulnerabilities.

1 Artigo elaborado para mesa redonda "Impactos, Vulnerabilidades, riscos e adaptações à variabilidade e mudanças climáticas”, no IX Simpósio Brasileiro de Climatologia Geográfica, em Fortaleza em setembro de 2010, revisado e ampliado para esta publicação. 


\section{INTRODUÇÃO}

As cidades de médio porte, de até 500 mil habitantes são os polos de atração das migrações, sejam provenientes da zona rural ou das metrópoles, devido ao desemprego, violência, poluição ou alta densidade populacional. As estatísticas demonstram uma tendência nacional de concentração da população na zona costeira. Essa zona, especialmente no Centro Sul, está sujeita às tempestades severas. Caracteriza-se ainda por um relevo bastante compartimentado de fortes declividades e planícies de inundação.

O modelo atual de crescimento urbano privilegia práticas sociais que conduzem ao adensamento e verticalização das construções, a compactação e impermeabilização do solo, à supressão da vegetação e cursos d'água e ao transporte individual, que recebe os maiores investimentos em infra-estrutura. $\mathrm{O}$ planejamento urbano está destinado à valorização imobiliária direcionando os investimentos em infraestruturas às áreas melhor localizadas, mais ventiladas, com as mais belas paisagens. As intervenções com obras públicas, para contenção de inundações e deslizamentos, são direcionadas aos espaços mais valorizados, nos centros de negócios, áreas industriais e principais vias de deslocamento de cargas, o que, no entanto, não tem evitado as interrupções do tráfego durante e após episódios pluviométricos intensos.

A preponderância das decisões do setor imobiliário sobre os planos urbanísticos e a ausência de políticas públicas no controle do uso do solo tem levado a população pobre a estabelecer assentamentos de padrão construtivo precário em áreas de risco como terrenos inundáveis em grotões de drenagem e encostas com forte declive (NOBRE et. al., 2010).

A vulnerabilidade, ou seja, os impactos danosos e previsíveis a que estão expostos as pessoas, a economia e o ambiente (VE-
YRET, 2007), decorrem da combinação de um relevo compartimentado, suscetível à erosão e inundações, a um clima tempestuoso e ao crescimento urbano acelerado, que tem criado espaços fragmentados e segregados espacialmente, que agravam a desigualdade social e degradação ambiental (NOBRE et. al., 2010). As soluções limitadas à execução de obras de engenharia que buscam se sobrepor à dinâmica dos processos naturais, acabam por comprometer a saúde e a vida das pessoas, as habitações, as atividades industriais, comerciais e de serviços públicos e privados, além do sistema de transporte urbano e rodoviário.

Nas décadas de 1980 e 1990, nenhum pesquisador poderia abordar eventos pluviais extremos ou a ausência de precipitação, caracterizando as estiagens, sem os relacioná-los à fase quente (El Niño) ou fria (La Niña) do Fenômeno El Niño-Oscilação Sul (ENOS/ENSO). Atualmente, e com mais ênfase a partir do início do século XXI, todos os desastres naturais, inclusive as inundações, passaram a ser atribuídas ao aquecimento global devido ao incremento dos gases estufa, causado pelo pela queima de combustíveis fósseis, da vegetação florestal, criação de gado e culturas inundadas como a do arroz.

A história geológica tem demonstrado que as mudanças climáticas globais fazem parte da dinâmica natural da Terra, que já vêm ocorrendo antes da humanidade, antes da urbanização. Ocorrem causadas por mecanismos astronômicos, geológicos, climatológicos, dos quais não temos controle. Com relação aos fenômenos atmosféricos extremos, sequer podemos prevê-los, seja o momento, amplitude ou localização. Eles ocorrem em diferentes escalas. Eles retornarão em 10, 20, 25, 50 ou 100 anos, tão mais espetaculares e destrutivos, quanto mais demorado seu período de retorno. Não obstante à insubordinação da atmosfera, nossa sociedade cria climas: microclimas, climas locais e até regionais, na escala de nossas regiões conurbadas e metropolitanas. Nes- 


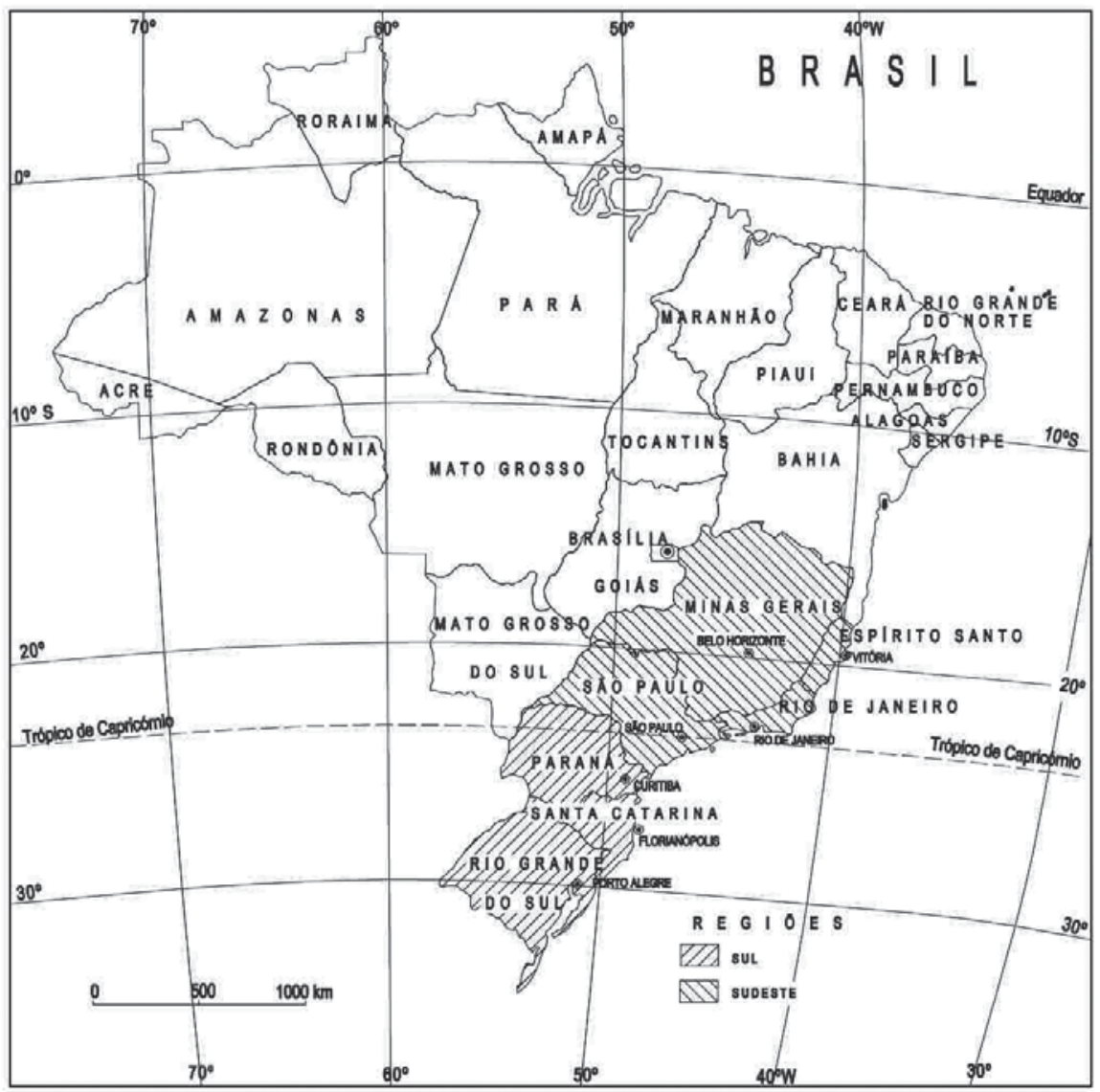

Figura 1 - Mapa de localização do Centro Sul do Brasil. Elaboração Prof. Luiz Antônio Paulino, supervisor do Laboratório de Geoprocessamento do Departamento de Geociências da Universidade Federal de Santa Catarina.

tas escalas há mudanças climáticas efetivamente causadas pela ação humana, que se pode comprovar pelo aumento das temperaturas, redução da umidade, inversão dos ventos regionais, aumento das precipitações localizadas. A urbanização, sem dúvida tem ampliado a ocorrência de inundações e deslizamentos, pela crescente desigualdade social que leva à ocupação de áreas de risco, carentes de obras de prevenção a eventos climáticos extremos, além da impermeabilização das superfícies pela supressão da vegetação e de corpos d'água e adensamento do espaço construido.

Chuvas intensas e inundações continuam marcando todos os verões do Centro Sul
(Fig.1) do Brasil e desorganizando o cotidiano dos brasileiros, mas sempre com maior repercussão nas regiões metropolitanas de São Paulo e Rio de Janeiro, Belo Horizonte e no Estado de Santa Catarina. As chuvas excepcionais geralmente provocam inundações e escorregamentos, deixando desabrigados, por vezes mortos, destruindo residências e outros tipos de edificações urbanas, além da infra-estrutura pública como pontes e estradas.

Este trabalho teve por objetivo analisar os condicionantes naturais e urbanos que explicam a ocorrência de inundações no Centro Sul do Brasil; relacionar a evolução da urbanização ao aumento da frequência de 
eventos de inundações e deslizamentos; comparar a ocorrência de eventos extremos às variabilidades climáticas e demonstrar que a sustentabilidade de nossas cidades não será alcançada apenas com obras de engenharia.

O planejamento urbano não tem considerado a relação entre as mudanças e variabilidades climáticas, as vulnerabilidades naturais da superfície terrestre e o crescimento das cidades.

\section{CONDICIONANTES NATURAIS E UR- BANOS}

O relevo do Centro Sul brasileiro é marcado por planaltos e chapadas no interior e serras costeiras (ROSS, 2001). Os relevos de maior altitude têm contatos abruptos, fortes declividades e vales profundos, que favoreceram a erosão e o assoreamento e consequentemente a formação de planícies colú- vio-aluviais, aluviais e marinhas que apresentam grande potencial para a inundação (Fig. 2). A configuração do relevo atual é consequência de um clima tempestuoso que segue esculpindo as superfícies, cada vez mais ocupada pela população brasileira. Tal ocupação se dá em ritmo acelerado por uma expansão urbana imbuida na eliminação da vegetação e na alteração do relevo a partir de aplainamentos e aterramentos e na impermeabilização da superfície pelo adensamento das construções que buscam obter a máxima valorização da propriedade da terra.

O clima desta região é bastante influenciado pelas invasões frontais e suas ondulações. No sul as frentes são os principais sistemas produtores de precipitação em qualquer estação do ano, principalmente em Florianópolis. Em São Paulo e Rio de Janeiro produzem menos chuva no inverno e chuvas intensas no verão em associação aos fluxos úmidos de noroeste vindos da Amazônia

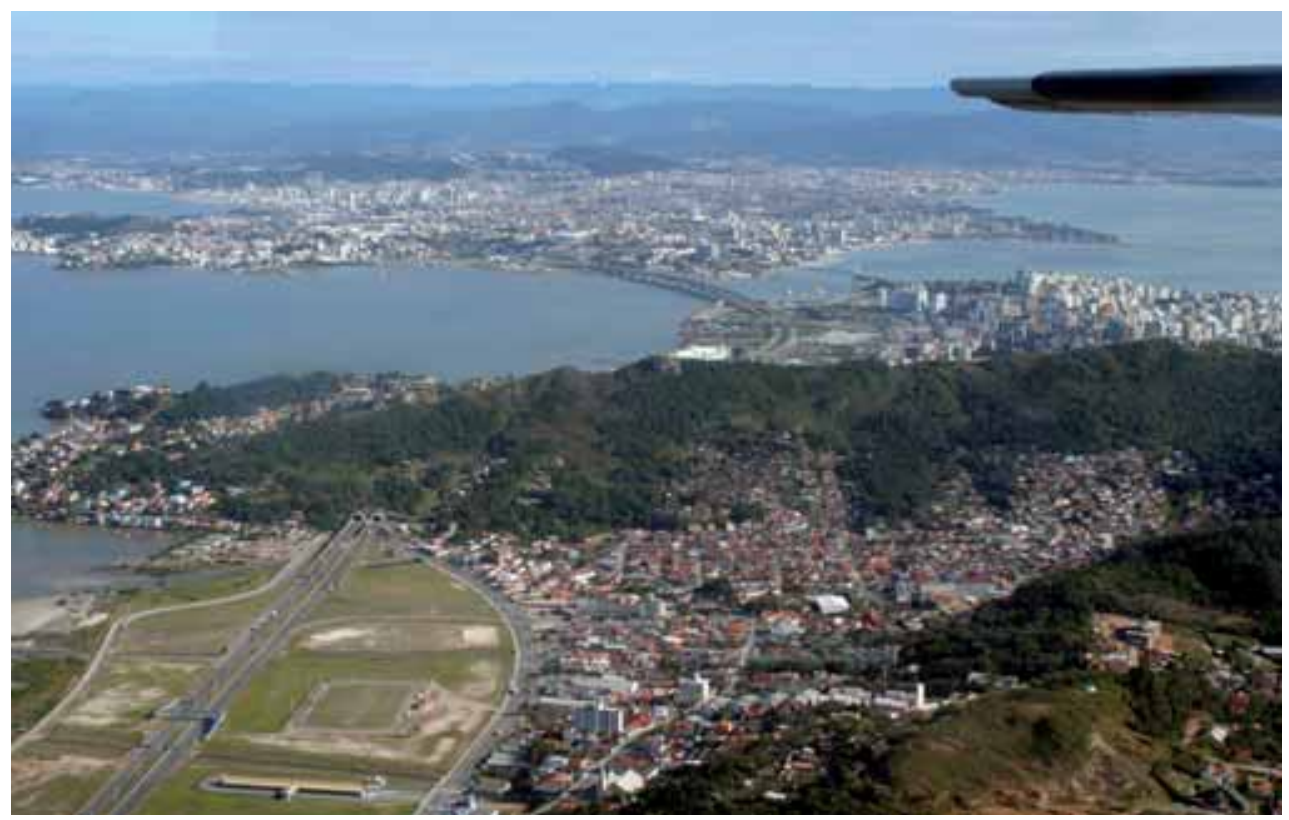

Figura 2 - Vista aérea da porção central da cidade de Florianópolis, Ilha de Santa Catarina e região adjacente, com destaque ao relevo costeiro em primeiro plano e ao planalto ao fundo. Fonte: Acervo Fotográfico - DEINFRA. 
que formam as Zonas de Convergência do Atlântico Sul (ZCAS). Na primavera os deslocamentos dos sistemas frontais produzem instabilidades no interior do continente, formando os Complexos Convectivos de Mesoescala, que são produtores de tempestades locais, aos quais as mesmas por vezes se associam. Esses sistemas (Fig. 3) causam em poucas horas precipitações torrenciais, que podem vir acompanhadas de granizo e tornados. Os tempos instáveis causados pelas frentes frias ocorrem também associados aos vórtices ciclônicos, aos cavados em baixos, médios e altos níveis atmosféricos, às baixas à superfície e aos jatos em médios e altos níveis (MONTEIRO, 2001). Chuvas torrenciais ocorrem no Centro Sul do Brasil em qualquer estação do ano e em diferentes configurações de grande escala (El Niño, La

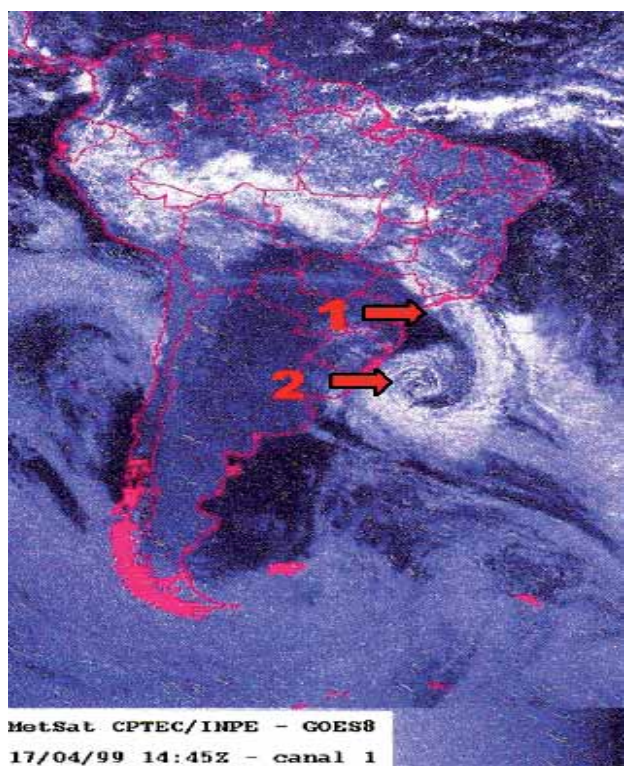

Niña). O clima da faixa costeira é bastante chuvoso também por influência das temperaturas do Oceano Atlântico e da circulação marítima que atua inclusive na região metropolitana de São Paulo a sotavento da Serra do Mar. No verão, a convecção tropical é a maior responsável pela mudança nas condições diárias de tempo, geralmente entre o entardecer e início da noite, com ocorrências de precipitações torrenciais, concentradas em menos de uma hora, pancadas isoladas de chuva "típicas de verão" que são, em parte, responsáveis pelo elevado índice pluviométrico dessa época do ano. As ZCAS no Sudeste influenciam na atuação da massa Tropical Continental (mTc) que causa estiagens no Sul, relação referida por SILVA E MARENGO (2002, apud MONTEIRO e MENDONÇA, 2006).
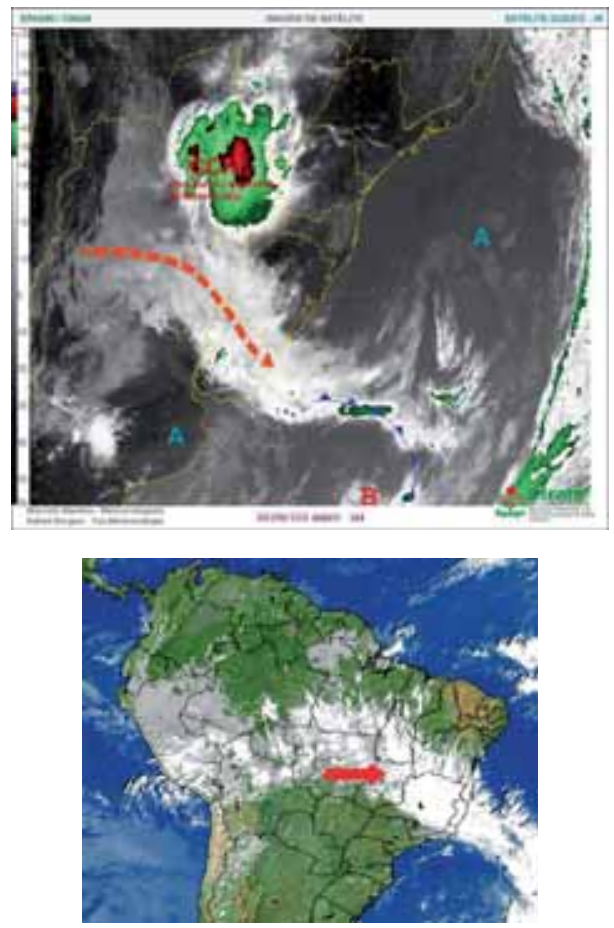

Figura 3 - Sistemas atmosféricos de superfície produtores de tempestades severas. Na primeira imagem uma Frente fria na Região Sudeste (1) e um Ciclone Extratropical na costa do Rio Grande do Sul (2). Na segunda, Zona de Convergência do Atlântico Sul (ZCAS) associada a chuvas intensas no Sudeste e estiagens no Sul. Na terceira, Complexo Convectivo de Mesoescala (CCM) deslocando-se do oeste. Ao sul do Brasil está a Corrente de Jato, sistema de altos níveis que acompanha a frente fria no Oceano. Fonte: MONTEIRO e MENDONÇA (2006) e EPAGRI/ CIRAM (2010). 
A combinação de um relevo susceptível à erosão e deslizamentos a um clima úmido e tempestuoso não têm sido considerado na ocupação e uso do solo em todo Centro Sul do Brasil.

\section{OS ANTECEDENTES HISTÓRICOS}

Todos os anos, em qualquer estação, repetem-se as manchetes sobre os desastres naturais, principalmente relacionados às inundações, deslizamentos, vendavais e tornados, entre outros fenômenos atmosféricos desencadeadores de catástrofes sociais, com afetados, desalojados, desabrigados, feridos e mortos. A informação rotineira destes eventos no noticiário dá à população a noção do aumento da vulnerabilidade de nossas cidades aos eventos climáticos e reforça a explicação de que isto é decorrente do aquecimento global. Há poucos anos, notícias deste tipo vinham associadas ao fenômeno ENOS (El Niño-Oscilação Sul), mas o crescimento da dificuldade da perfeita correlação consolidou a hipótese do aquecimento global. Entretanto os desastres naturais, como as inundações não são fenômenos recentes no Brasil, apenas se tornaram rotineiros e catastróficos.

O botânico Auguste Saint-Hilaire, que percorreu o Centro Sul do Brasil, entre 1816 e 1822, escreveu com detalhes episódios extremos, relacionados à intensidade das chuvas, ocorrência de granizo e neve; à temperatura, sobre ondas de calor e geadas; aos vendavais e às tormentas. Relatou a ocorrência de um tornado na região das missões gaúchas em abril de 1821, que por mais de 10 minutos causou destruição e enormes prejuízos. Registrou a ocorrência de araucárias nos arredores de São Paulo e mencionou o fato da planície do Tietê permanecer inundada por dois a três meses, beneficiando a agricultura, além da cobertura de neve, nos meses de inverno, sobre os picos mais altos da região serrana entre São Paulo e o Rio de Janeiro, demonstrando a influência da Pequena Idade do Gelo também sobre o clima brasileiro (SANT'ANNA NETO, 2004), O estadunidense Thomas Ewbank em 1845 e 1846 relatou que dos quase dois meses que esteve no Rio de Janeiro, choveu mais de 40 dias (fevereiro e março), com a ocorrência de fortes tempestades e trovoadas, sempre sob um forte calor, uniforme ao longo do dia e da noite (SANT'ANNA NETO, 2004). Cruls em 1892 analisou o período de 1851 a 1890, com base nos dados do Observatório do Rio de Janeiro, relatando temperaturas extremas, máxima absoluta em dezembro de $39^{\circ} \mathrm{C}$ e mínima absoluta em setembro de $10,2^{\circ} \mathrm{C}$ (BRANDÃO, 2001).

Viajantes estrangeiros que estiveram na Ilha de Santa Catarina (atual Florianópolis) nos séculos XVIII e XIX também foram impactados pelo clima da época. George Anson chegou à Ilha na segunda quinzena de dezembro de 1740 e atribui à vegetação exuberante, a persistência de um nevoeiro noturno que se estendia por parte considerável da manhã, dissipando-se com o aumento da radiação solar ou pela brisa marinha. JeanFrancois G. de La Pérouse, relatou ter enfrentado uma violenta tempestade no dia 25 de outubro de 1785 e mau tempo até a chegada à Ilha quando foram envolvidos por uma neblina que caracterizou como "mais densa do que encontrada nas costa da Bretanha, em pleno inverno". Durante sua estadia de 12 dias o céu esteve sempre encoberto. Urey Lisianky se aproximou da Ilha nos dias 16 e 17 de dezembro de 1803, porém só aportou no dia 21 em função da má visibilidade que se estendeu até o meio-dia do dia 18, seguida por ocorrência de tempestade com chuva à tarde, vento forte à noite e ondas altas. G. H. von Langsdorf, nesta mesma época, descreve as tempestades de verão (HARO, 1996).

\section{TEMPESTADES LOCAIS SEVERAS}

A maior parte dos sistemas meteorológicos atuantes no Centro Sul do Brasil, associados às massas de ar e frentes, são produtores de tempestades locais severas. Estas se 
caracterizam por chuvas torrenciais localizadas, acompanhadas, em geral, de trovões, descargas elétricas, granizos, ventos fortes, súbitas variações de temperaturas e até tornados. As tempestades locais estão associadas ao cumulonimbus, nuvens de grande desenvolvimento vertical que podem se estender de $300 \mathrm{~m}$ na base até atingir de 9.000 a $18.000 \mathrm{~m}$. As nuvens causadoras das tempestades locais severas estão associadas à presença de ar quente, úmido e estável, seja no interior de uma massa de ar, ao longo de uma frente ou em uma linha de instabilidade, bem como, não raramente, em regiões montanhosas. Quando associadas ao aquecimento diurno intenso, atingem maiores proporções à tarde; porém quando associadas às frentes ocorrem a qualquer hora seguindo o sentido do deslocamento das frentes, podendo ser intensificadas localmente por influência do relevo e pela penetração do ar frio que força a subida do ar quente instabilizando-o. As tempestades locais severas podem durar de uma a duas horas, tempo do ciclo da nuvem. As precipitações são acompanhadas de ventos fortes e rajadas, podendo totalizar em apenas uma hora até $500 \mathrm{~mm}$. Precipitações desta proporção podem causar inundações catastróficas em sítios urbanos, locais confinados ou de drenagem deficiente. Não raro, as tempestades severas resultam de uma família de nuvens tempestuosas, reproduzidas umas a partir das outras que já estão precipitando, por influência da cunha de frio, que acompanha a chuva e o gelo que caem dos níveis superiores, e que origina nova célula de convecção (VIANELLO e ALVES, 1991). A figura 4 mostra a distribuição de tempestades severas no Globo, onde a porção da América do Sul, a leste da Cordilheira dos Andes, destaca-se pela alta frequência de ocorrência de tempestades severas locais. No Brasil observa-se uma área onde a frequência é ain-

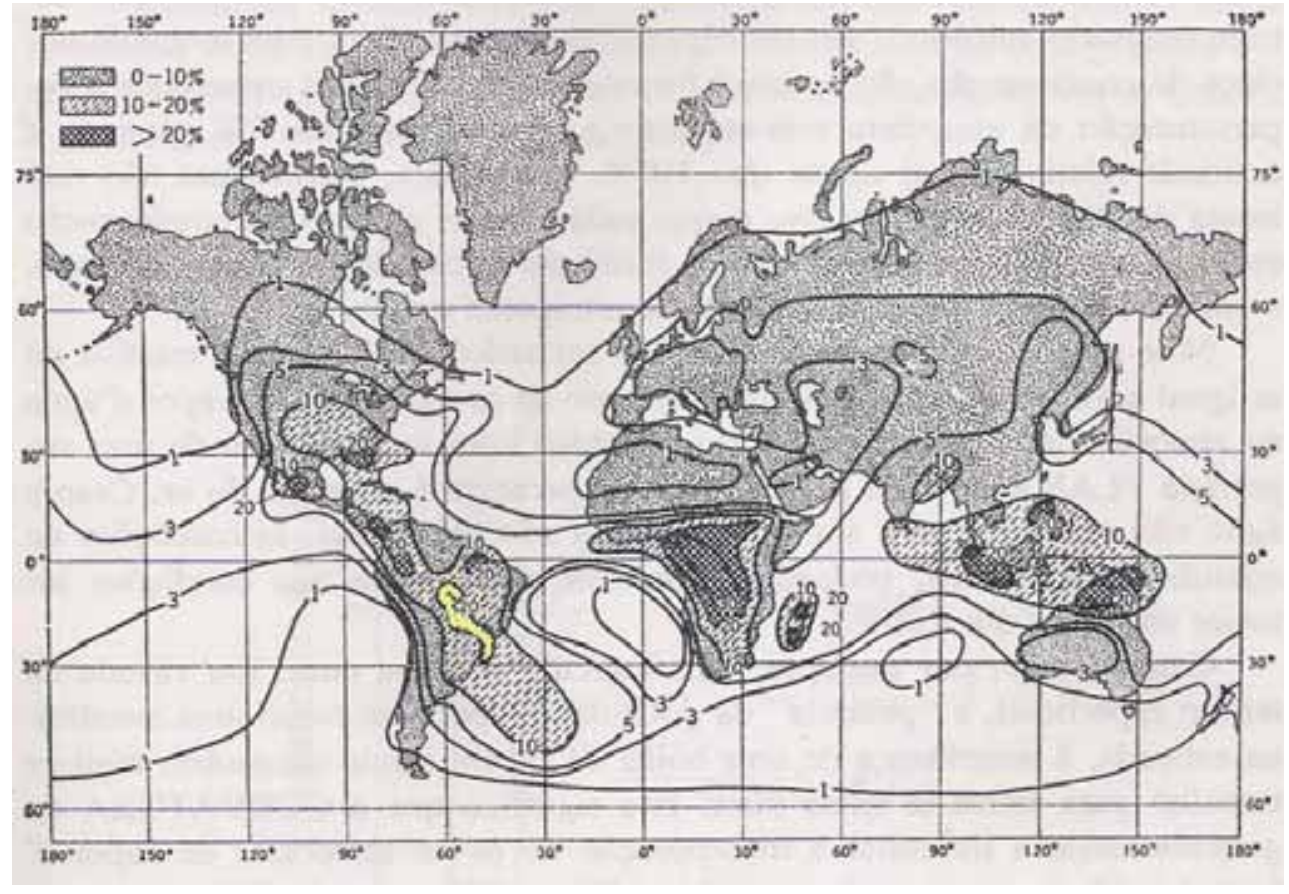

Figura 4 - Distribuição Mundial de Tempestades Severas. As isolinhas referem-se à frequência em relação à ocorrência total (PETTERSSEN, 1968 apud VIANELLO \& ALVES, 1991). A cor amarela destaca a região do Centro Sul atingida por mais de $20 \%$ das tempestades severas. 
da mais alta, superior a $20 \%$ da frequência mundial (PETTERSSEN, 1968 apud VIANELLO e ALVES, 1991). As maiores cidades, mais populosas e densamente ocupadas localizam-se exatamente aí, como é o caso das capitais São Paulo, Rio de Janeiro e Florianópolis. A inserção desta figura de 1968 demonstra que a suscetibilidade ambiental da região já é conhecida e registrada a mais de 30 anos. Entretanto, permanece ignorada pelos tomadores de decisão, uma vez que tem aumentado a frequência de episódios catastróficos associados a eventos pluviais intensos e aos padrões de uso e ocupação do solo urbano.

\section{VARIABILIDADES CLIMÁTICAS}

Atualmente se tem atribuido temperaturas extremas, precipitações anômalas e concentradas e fortes ondas de frio como expressões de uma mudança climática. Entretanto pouco se divulga os conceitos de flutuações e variações do clima. Estudos clássicos como o de NIMER (1989) sobre as regiões brasileiras, baseados nas normais climatológicas (1914-1938), referem à variabilidade pluviométrica e desvio médio anual em relação à normal para o sul o Brasil, reportando a anos de fortes desvios negativos $(1917,1921,1924$ e 1930) e positivos (1928 e 1932):

"Com efeito, em determinados anos, embora estes sejam raros, a precipitação torna-se tão abundante que em certas áreas chega a atingir a totais equivalentes ao dobro (ou até mais) da precipitação média, representativa da normal, enquanto que em outros anos, também raros, o decréscimo é tão notável que a acumulada fica aquém da metade da precipitação média" (NIMER, 1989, p. 221).

Com relação às temperaturas, com dados relativos às normais até 1942, são reportadas para a Região Sul temperaturas máximas de $38^{\circ} \mathrm{C}$ a $34^{\circ} \mathrm{C}$ da costa às regiões mais elevadas dos planaltos. No sudoeste do Rio Grande do Sul e Santa Catarina, Vale do Itajaí e norte do Paraná foram registradas temperaturas absolutas de $40^{\circ} \mathrm{C}$ a $42^{\circ} \mathrm{C}$. As temperaturas mínimas absolutas no período distribuíram-se de $0^{\circ}$ a $-8^{\circ} \mathrm{C}$ da costa para o interior, alcançando $10^{\circ} \mathrm{C}$ negativo nos relevos mais elevados (NIMER, 1989).

Há vários termos para descrever as variações climáticas como variabilidade, flutuações, tendências ciclos e mudanças. Estes termos devem ser adequados a escalas temporais específicas. A variabilidade climática, que inclui flutuações dentro de um período menor do que 30-35 anos é muito rápida para ser considerada como mudança climática (AYOADE, 1988).

O Fenômeno ENOS-El Niño/La Niña, influencia na flutuação climática na região Centro Sul, por atuar no ritmo de deslocamento das frentes. No Sul em anos de El Niño, o Jato Subtropical, torna-se mais intenso, bloqueando os sistemas frontais que permanecem estacionários, aumentando a temperatura média e a precipitação na primavera do ano de início do fenômeno e no outono e inverno, maio a julho do ano seguinte, principalmente nas áreas costeiras (CIRAM/EPAGRI, 1999b e c). No Sudeste verifica-se moderado aumento das temperaturas médias (CPTEC/INPE, 2010). Nos anos La Niña a rápida passagem das frentes atua na diminuição das temperaturas médias e no total de precipitação, sendo os menores registrados na primavera. No Sul do Brasil, verifica-se uma tendência à diminuição da precipitação nos meses de junho a dezembro do ano de início do fenômeno (GRIMM et. al., 1998). No Sudeste é baixa a previsibilidade de La Niña (CPTEC/INPE, 2010). No entanto em 2010 observou-se forte queda de temperatura no Centro Sul do país.

As fases do Fenômeno ENOS - El Niño/ La Niña têm duração de 6 a 18 meses. O ano de 1964, caracterizado pela ocorrência de La Niña moderado, considerado o menos chuvoso, registrou em Florianópolis total de 
$823,8 \mathrm{~mm}$, com maior percentual na primavera; enquanto em 1983, ano El Niño forte, excepcionalmente chuvoso, registrou-se total de 2598,5 mm, com maior percentual no inverno (HERRMANN, 1999).

KAYANO E ANDREOLI (2009) referemse a variabilidades de baixa frequência, com escalas de decenal a multidecenal, que ocorrem no Pacífico e Atlântico, sobrepondo-se aos modos interanuais, como o fenômeno ENOS, alterando o efeito deste inclusive na América do Sul. As referidas autoras, numa revisão bibliográfica, apresentam uma discussão em torno deste tipo de variabilidade, demonstrando não haver consenso ainda.

Em torno deste tema MOLION (2005), sustenta a variabilidade interdecadal descrita por MANTUA et. al. (1997) denominada Oscilação Decadal do Pacífico (ODP) que persiste por 20 a 30 anos e como o fenômeno ENOS, também apresenta duas fases: quente e fria. Na fase fria prevalecem anomalias negativas de Temperatura na Superfície do Mar (TSM) no Pacífico Tropical e, simultaneamente, anomalias de TSM positivas no Pacífico Extratropical em ambos os hemisférios. Na fase quente, ao contrário, as anomalias de TSM positivas ocorrem no Pacífico Tropical e as negativas no Pacífico Extratropical. Nos últimos 150 anos, após uma fase de transição da Pequena Idade do Gelo, foram identificadas duas fases frias 1900-1924 e 1947-1976 e duas fases quentes $1925-1946$ e de 1977 a meados dos anos 90. Alguns autores sugerem outra mudança no regime da ODP por volta de 1998/1999 (KAYANO e ANDREOLI, 2009). Nas fases já estudadas a temperatura variou de $4^{\circ}$ positivos nas fases quentes para $2^{\circ}$ negativos na fase fria. Nas fases quentes ocorreram pelo menos cinco eventos de El Niño fortes, enquanto na fase fria foram sete eventos $\mathrm{La}$ Niña fortes (MOLION, 2008). Na fase fria da ODP, os eventos El Niño e La Niña têm frequências equivalentes ao passo que nas fases quentes os eventos El Niño são mais frequentes e intensos (KAYANO e ANDREOLI, 2009).
A causa da ODP é ainda bastante discutida, pois a passagem de um regime para o próximo é abrupta (KAYANO e ANDREOLI, 2009). Os impactos desta variabilidade sobre os climas começam a ser estudados, porém, cada vez mais se reconhece o papel dos oceanos sobre a atmosfera. O Pacífico, que ocupa um terço da superfície terrestre, certamente contribui significativamente para a caracterização e variabilidade climática (MOLION, 2005) e todos os estudos sobre o fenômeno ENOS têm mostrado sistematicamente isto.

\section{IDENTIFICANDO AS FASES DA ODP NO CLIMA CATARINENSE}

A primeira pesquisa que alertou para uma possível variabilidade, ou pelo menos despertou desconfiança em relação a uma tendência ao aquecimento global foi sobre geada. AGUIAR e MENDONÇA (2004) apresentam um gráfico com a distribuição das geadas em Santa Catarina onde se percebe um incremento dos eventos a partir de 1996 (Fig.5).

Observando-se o gráfico percebe-se que a partir de 1996 aumentou o número de ocorrência de geadas em Santa Catarina e embora haja uma correlação entre as geadas e o fenômeno La Niña, nesse período, em que possivelmente inicia a nova fase fria da ODP, sua ocorrência foi alta, mais de 55 anuais, inclusive em anos de El Niño. SPINELLI (2009) realizou uma climatologia das geadas, no período de 1960-2008 em Caçador, município situado ao norte do meio oeste catarinense (Fig.6). Obteve com tais dados boa correlação entre as fases frias e quentes da ODP, com média de 25 geadas no período 1947-1976 e 21 no período 1977-1998. Na fase fria foram registrados totais de 35 a 40 geadas anuais nos anos de 1962, 1964, 1968 e 1974 e geadas tardias nos meses de novembro e dezembro em 1964, 1970 e 1971, percebendo-se que houve muitos anos frios nos últimos 15 anos da fase. Na fase quente destacaram- 


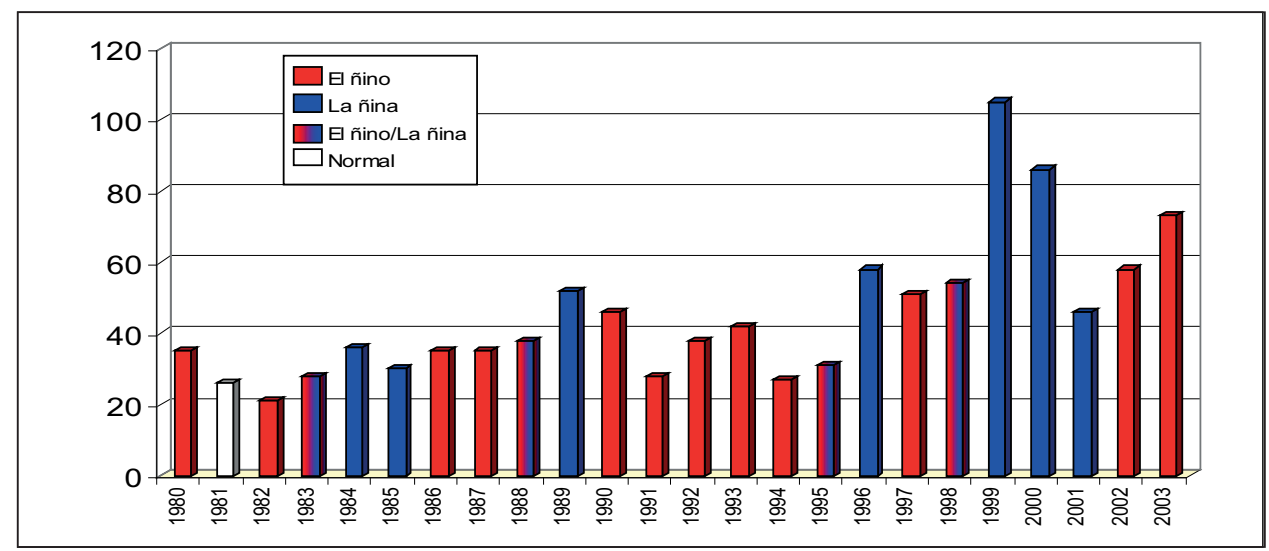

Figura 5 - Total anual de geadas ocorridas em Santa Catarina de 1980 a 2004. AGUIAR e MENDONÇA (2004)

se em número de ocorrências de geadas os anos de 1978 e 1979 de El Niño fraco a neutro; 1989, ano de La Niña forte e 1990 (SPINELLI, 2009) que aparece como neutro (CIRAM/EPAGRI, 2010). Nesta fase a ocorrência das geadas estendeu-se de abril a outubro (Fig.7). Os anos de 1976 e 1998, os últimos da fase fria e quente, respectivamente, registraram geadas precoces em março (SPINELLI, 2009). As geadas precoces e tardias são as mais prejudiciais a atividade agrícola. O ano de 1996 também registrou quase 30 eventos de geadas, expressando o aumento também verificado no estado a partir deste ano (AGUIAR e MENDONÇA, 2004). Na fase fria atual destacam-se em número de geadas, acima da média, os anos de 1999 e 2000, com quase 30 eventos e 2003, 2006 e 2007, como menos de 25. Nos anos de 2004, 2005 e 2008, o número de geadas ficou entre 10 e 15 , não se percebendo uma tendência ao resfriamento ainda, pois a ocorrência se estendeu como na fase quente anterior entre abril e outubro (SPINELLI, 2009). Ressalta-se que nessa fase se está analisando apenas os primeiros nove anos de uma variabilidade que pode estender-se acima de 20 anos.

MOLION (2008) cita CHRISTY e SPENCER (2004), que demonstram, por meio de dados de Microwave Sounding Units
(MSU) a bordo de satélites desde 1979, que as temperaturas médias globais aumentaram quando da ocorrência de eventos El Niño e diminuíram quando da ocorrência dos La Niña. No evento El Niño forte de 1997/98, a temperatura média global chegou a apresentar uma anomalia positiva de aproximadamente $0,75^{\circ} \mathrm{C}$ em abril de 1998 enquanto, no La Niña de 1984/85, as anomalias de setembro de 1984 chegaram a $-0,50^{\circ} \mathrm{C}$. O aumento significativo no número de geadas nos anos 1992-1993 pode ser explicado pela presença dos aerossóis da erupção Monte Pinatubo (Filipinas, junho de 1991) que influenciou no resfriamento do Planeta nos anos seguintes (MOLION, 2005). No ano de 1996, na fase quente da ODP, além de La Niña fraca, as manchas solares estiveram ausentes por mais de 150 dias (PHILLIPS, 2008). A baixa intensidade solar também pode ter influenciado na ocorrência de quase 60 eventos de geadas. MOLION (2005) compara as tendências da temperatura média global da troposfera nos últimos 25 anos, que apresentaram significativa diferença. Enquanto os dados de MSU apontam para apenas $+0,08^{\circ} \mathrm{C}$ as estações de superfície indicam uma tendência igual a $0,32^{\circ} \mathrm{C}$. Esta maior tendência apresentada bem poderia ser representada pelos climas urbanos de nossas cidades que já apresentam ilhas de calor com diferenças 


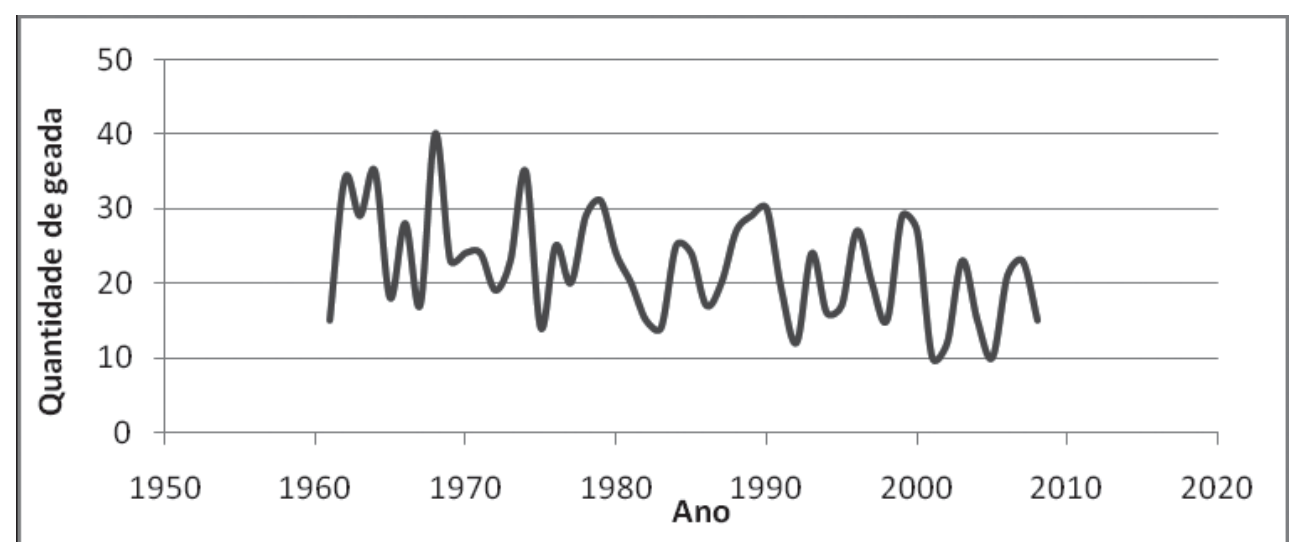

Figura 6 - Ocorrência de geada anual em Caçador (1961-2008). Fonte: EPAGRI/CIRAN. Elaborado por Katia Spinelli.
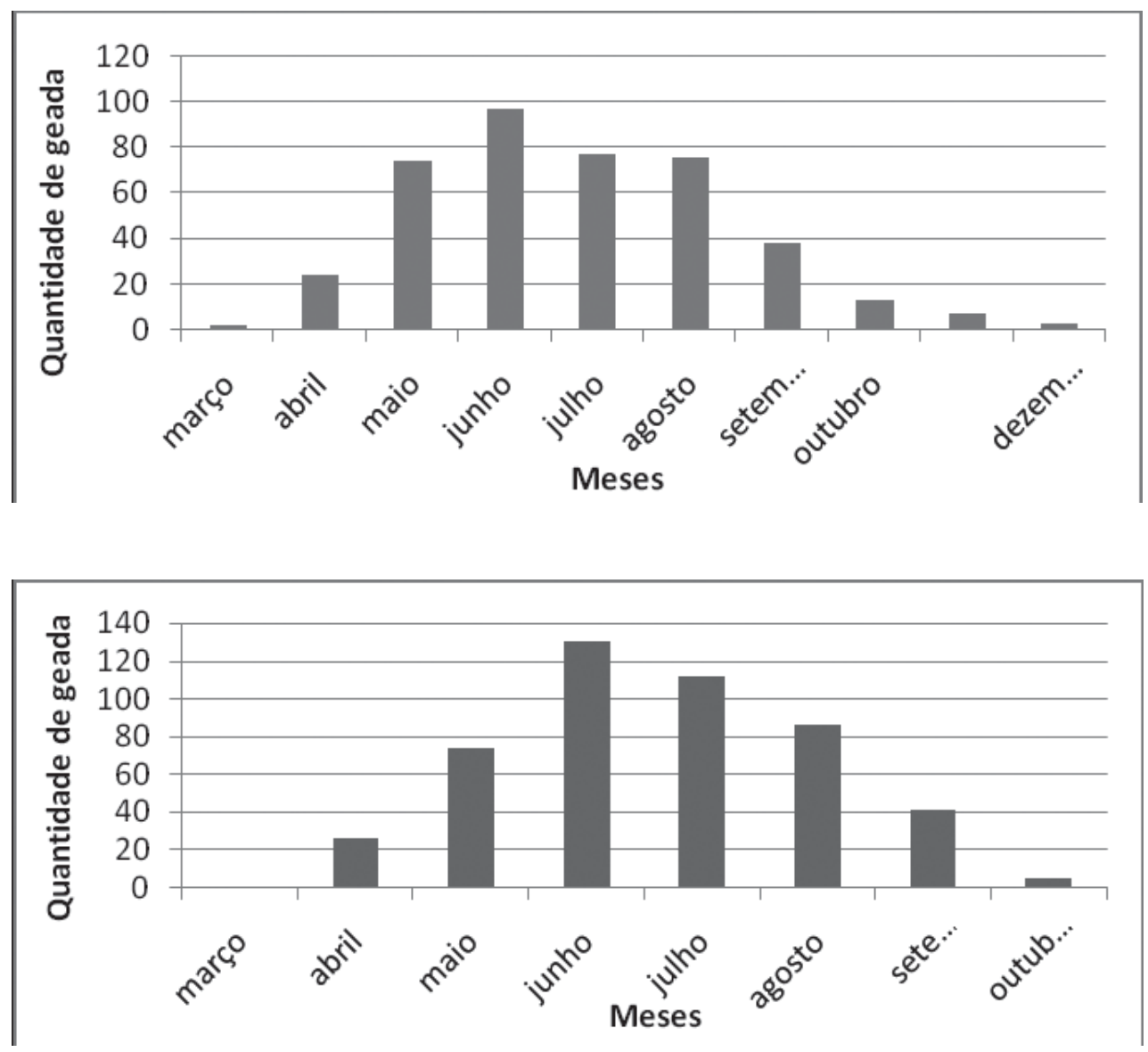

Figura 7 - Ocorrência mensal de geada nas fases da ODP fria de 1961-1975 e quente de 19761998, respectivamente, onde se observa uma expansão do período de geadas na fase fria. Fonte: EPAGRI/CIRAN. Elaborado por Katia Spinelli 
superiores a $5^{\circ} \mathrm{C}$ em relação às áreas adjacentes.

MARQUES (2010) analisou a variabilidade da precipitação pluviométrica na Bacia do Rio Tubarão (BHRT) no Sul de Santa Catarina. A partir de dados de seis estações da rede da Agência Nacional de Águas (ANA), do período de 1946 a 2006 analisou a distribuição sazonal e anual da precipitação pluviométrica relacionando a climatologia da chuva com a ODP. A comparação do Índice de ODP com os dados de precipitação anual na BHRT foi realizada a partir de um gráfico para cada localidade com o índice padronizado, para tornar os parâmetros de diferentes grandezas comparáveis. Todas as seis estações apresentaram anomalias negativas na precipitação até a metade da década de 1970, enquanto a partir daí predominaram as anomalias positivas, coincidindo com a mudança de fases, de fria para quente. Constata-se pelas figuras que as anomalias podem variar de uma estação pluviométrica para outra, entretanto mantendo a consistência das tendências negativas e positivas, dadas por condições climáticas mais frias e mais quentes, respectivamente, obedecendo à abrupta passagem de uma fase da ODP para outra. MARQUES (2010) cita outras localidades em que se verificaram as mesmas tendências como na bacia do Rio Paraguai e localidades gaúchas. Apresenta ainda o índice padronizado para a estação Urussanga, vizinha à BHRT, com dados de 1924 a 2004, onde também se identifica as anomalias positivas da primeira fase quente da ODP do século XX (Fig.8). Outra tendência observada por MARQUES (2010) foi o incremento das chuvas, sobretudo na primavera e verão, além da tendência de aumento dos dias de precipitações concentradas de $50 \mathrm{~mm}$ e $100 \mathrm{~mm}$ na primavera e verão, nos decênios das fases frias, embora em algumas estações maior número de dias também tenha ocorrido na fase quente.

Nos anos de 2001 a 2006 registrou-se no estado de Santa Catarina um período de fortes estiagens que causaram perdas econômicas. Os eventos de estiagem identificados nesse período não apresentaram qualquer correlação com as fases do fenômeno ENOS. De 2002 a 2006 as Temperaturas da Superfície do Mar (TSM) estiveram acima de $0,5^{\circ} \mathrm{C}$, nas regiões Niño 3 e Niño 3.4 caracterizando por vários trimestres o fenômeno $\mathrm{El}$ Nino (SACCO, 2010), para o qual sempre são esperados totais de precipitações elevadas. Por outro lado as estiagens correram

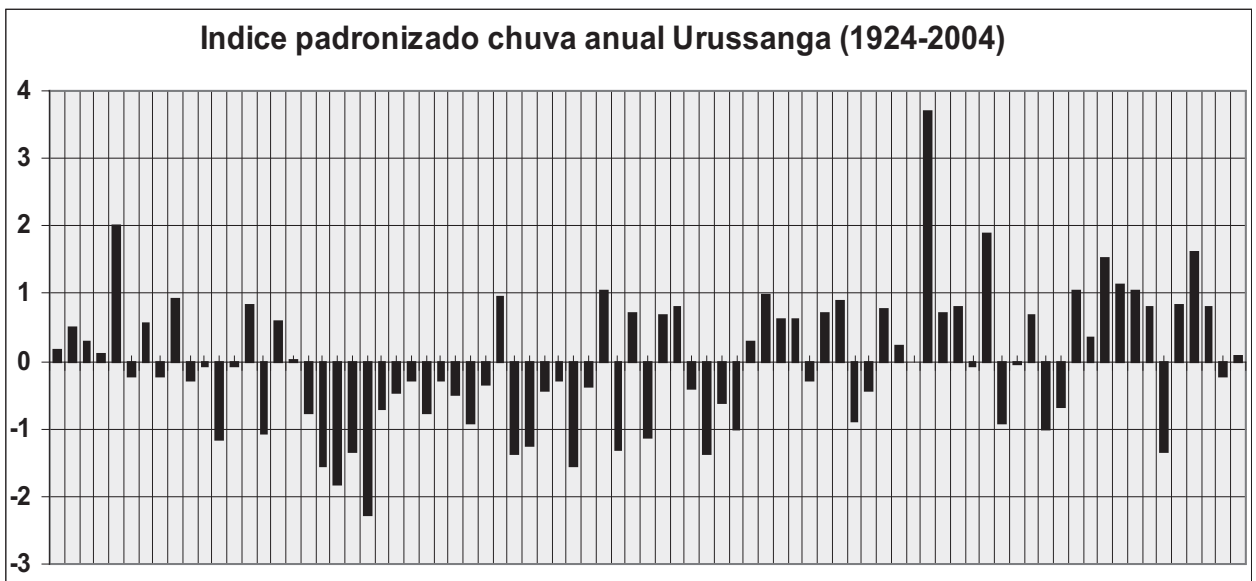

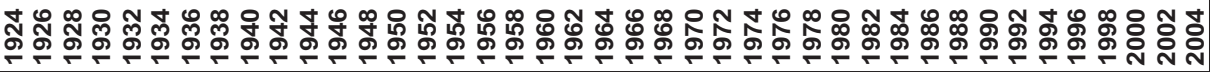

Figura 8 - Índices padronizados da chuva anual em Urussanga, identificando as três fases da Oscilação Decadal do Pacífico, registradas no século XX. Fonte: Rafael Marques (2010). 
nos anos da nova fase da ODP que teria se iniciado em 1999. O evento de 2006, caracterizado por apresentar precipitações $60 \%$ abaixo da média nos meses de maio, junho e julho, com mais de quinze dias consecutivos sem chuva no mês de maio, foi precedido, por outro evento longo, com um intervalo de apenas dois meses, o que agravou ainda mais as consequencias da falta de chuva na Mesorregião Oeste Catarinense.

Dos 92 dias de duração do evento, em 75 foi identificada ocorrência de bloqueios atmosféricos, correspondendo a $75 \%$ do período total. Não foi encontrada nenhuma correlação com eventos La Niña, apenas com condições de neutralidade e El Niño fraco (SACCO, 2010). Esta falta de correlação entre estiagem e La Niña reforça a hipótese da influência da nova fase fria da ODP, sobrepondo-se à variabilidade interanual.

As fases da ODP representam mudanças substanciais nos climas, apesar de sua expressão regional/local. Percebe-se claramente uma tendência de redução de temperaturas e precipitações na fase fria e aumento do número de dias de chuvas concentradas, conforme resultados de MARQUES (2010). As fases quentes apresentam menor quantidade média de geadas (SPINELLI, 2009) o que pressupõe temperaturas médias mais altas, maiores totais de precipitação e chuvas melhor distribuídas, inclusive pelo aumento no número de dias de chuvas (MARQUES, 2010). As estiagens do início do século XXI, caracterizadas por SACCO (2010), contrastam com os eventos de inundações que caracterizaram o final do século $\mathrm{XX}$.

A variabilidade climática que tem sido identificada nos remete à teoria de biostasia e resistasia de Erhart (1966). Na biostasia ocorre a dissecação vertical do relevo pela drenagem fluvial numa área com cobertura vegetal e latossolos. Na resistasia predomínio da erosão lateral pela ausência ou pouca cobertura vegetal e aplainamento do relevo (VITTE, 2009) Para Alves (2007), as intervenções do homem na vegetação e no solo produzem também efeitos de biostasia e resistasia, representando a primeira, uma fase de equilíbrio climácico, em que os seres vivos e os solos têm seu desenvolvimento máximo, ao passo que a segunda, a fase de alteração sensível no equilíbrio, provocando a instabilidade. A teoria da biostasia e resistasia revolucionou a geomorfologia, a partir do entendimento de que as variações climáticas do úmido para o seco é que explicariam a evolução do relevo brasileiro. Essa noção foi aplicada para as fases glaciais e interglaciais do Quaternário (VITTE, 2009). Entretanto, levando-se em consideração a hierarquia escalar espaçotemporal, tão fundamental na observação e explicação dos fenômenos geográficos, é possível associar as fases da ODP à escala humana da biostasia e resistasia; considerar que um período pouco superior a 20 anos também poderia causar alguma modificação no relevo local, caso pudesse afetar principalmente a cobertura vegetal. Neste sentido, a radical intervenção produzida por nossas cidades, eliminando a vegetação em função da expansão urbana, já tem causado modificações no relevo, que desestabilizado pelas edificações, estradas e canalizações, se modifica, deslocando-se por processos de deslizamentos. Essa intervenção do final da década de 60 para a primeira década do século XXI foi realmente significativa. É possível que o crescimento urbano e o agronegócio sejam ainda mais impactados pelos eventos climáticos nas próximas décadas. Não por um possível aquecimento global, mas por longos periodos de estiagens, seguidos de precipitações concentradas que além de inundações poderão causar deslizamentos, bem como geadas mais frequentes, intensas e que se estendam de março a dezembro, principalmente nos terrenos mais altos. Um paralelo pode ser feito entre as inundações de 1983 e os deslizamentos de 2008 na região do Vale do Itajaí em Santa Catarina. Em 1983, na fase quente de ODP, sob atuação do El Niño, o vale ficou inundado por vários dias no mês de julho. Como consequiência houve a valorização 
dos terrenos nos morros da cidade e quem pode se deslocou das áreas afetadas pelas inundações. Em 2008, sob atuação de La Niña de moderado a fraco, já na fase fria da ODP, no final de novembro houve, significativos deslizamentos em toda região de Blumenau. Este evento foi precedido por anos anteriores de longas estiagens no período de 2001 a 2006 e de fortes geadas nos anos 1999 e 2000. Periodos mais frios, com ausência de precipitações e ocorrências concentradas, retração da vegetação e domínio de processos de erosão, transporte e acumulação caracterizam a resistasia (SUGUIO,1998). Nossas paisagens encontramse cada vez mais desprovidas de vegetação e instabilizadas pela ocupação, assim, se efetivamente se caracterizar uma nova fase fria de ODP, será necessário repensar o ordenamento territorial, pois teremos todos os fatores necessários para gerarmos grandes desastres naturais mais catastróficos do que os que vivemos na fase quente da ODP no período 1977-1998.

\section{A EVOLUÇÃO DA VULNERABILIDA- DE URBANA}

O Rio de Janeiro já era urbano e já estava submetido a transformações urbanas no início do século XIX. No final deste, já apresentava favelas, com a ocupação das encostas dos morros. Na década de 40, a valorização das terras dá inicio ao crescimento vertical das edificações, à frota de automóveis e à favelização, (Fig.9 e 10) agravando os problemas urbanos devido ao aumento da frequência dos impactos ambientais ligados especialmente à poluição e às inundações (BRANDÃO, 2001).

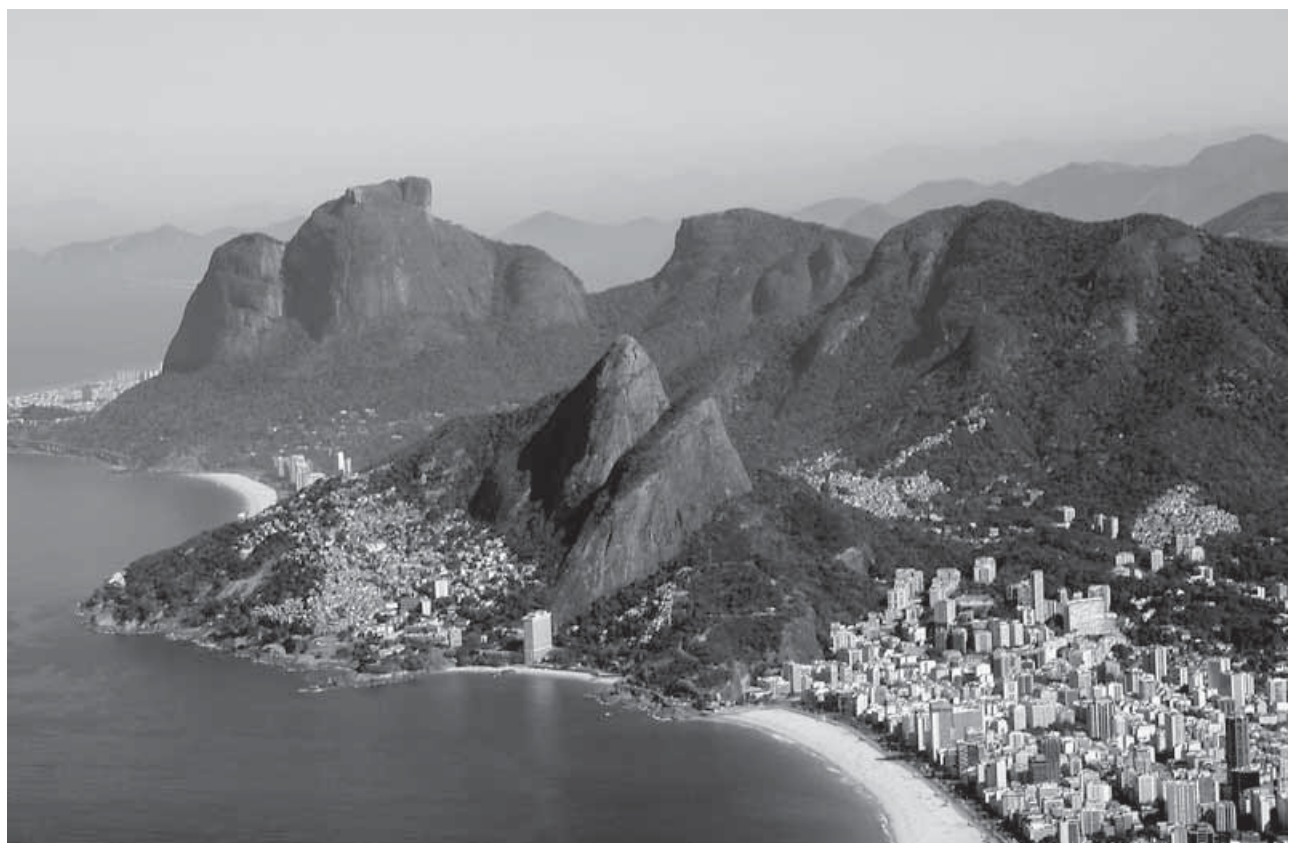

Figura 9 - Morro Dois Irmãos e Pedra da Gávea e os contrastes entre os edifícios à beira mar e as favelas nas encostas declivosas.Fonte: http://www.skyscrapercity.com/showthread.php?t=455738 


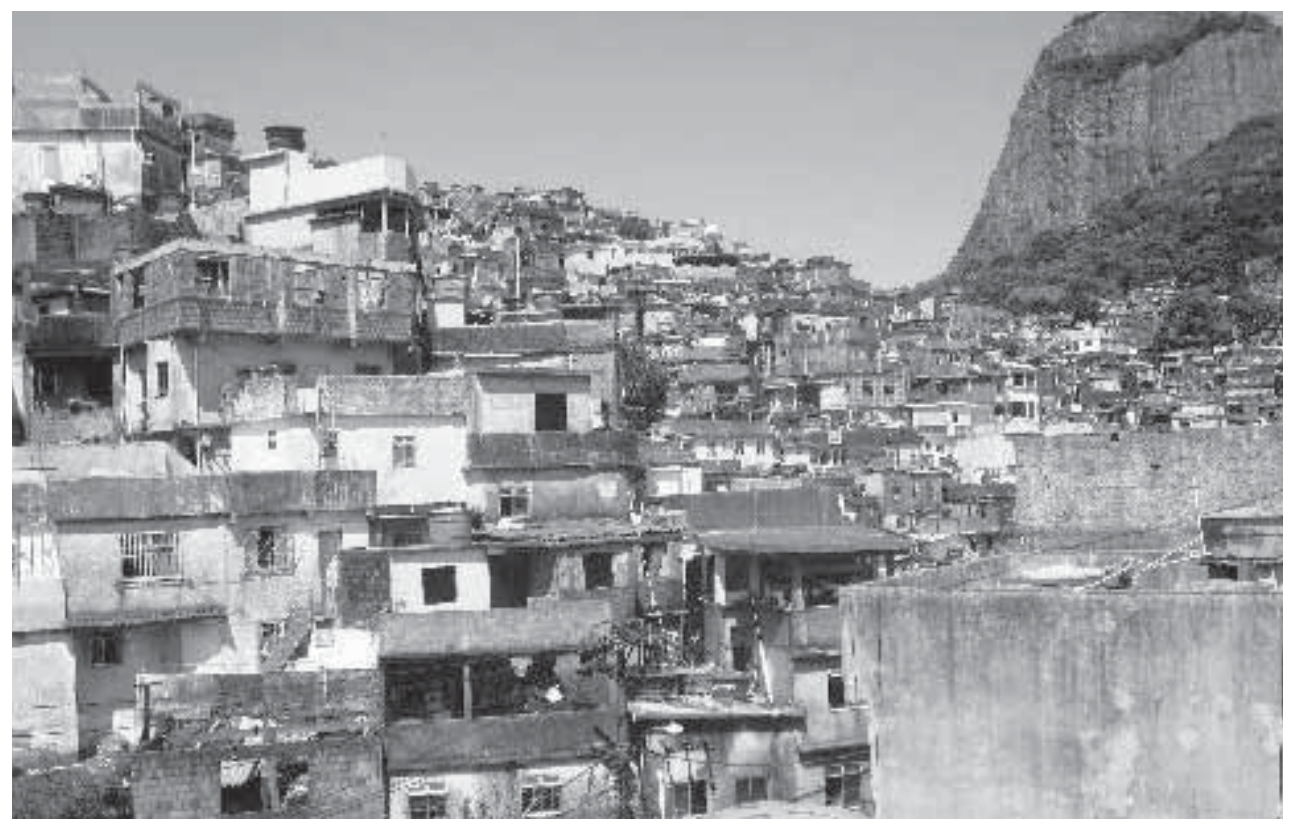

Figura 10 - Favela da Rocinha. Fonte: http://www.tripadvisor.com.br/LocationPhotos-g303506-w9Rio_de_Janeiro_State_of_Rio_de_Janeiro.html\#24295603.

O crescimento urbano de São Paulo se iniciou no final do século XIX e se acelerou no início do XX. A partir da II Guerra Mundial, ocorreu o crescimento tentacular da cidade e a formação da Área Metropolitana, com uma periferia carente em infra-estrutura e ocupada pela população pobre. A expansão da metropolização a partir de 1950 se reflete na ocupação de extensas áreas suburbanas, adensamento de áreas urbanizadas e crescimento vertical intenso (Figs.11 e 12) As rodovias também passam a contribuir para expansão da urbanização. O setor industrial e de serviços, cresce em ritmo acelerado até a década de 1970, quando o relevo, os reservatórios de água e a legislação se interpõem à expansão. A valorização da terra leva as empresas, bem como a população de baixa renda a localizarse na periferia, onde, ao contrário do centro, que se caracteriza por um adensamento de verticalização, há um excesso de dispersão e um aumento dos custos operacionais. A perda das áreas com vegetação agrava a qualidade ambiental, gerando microclimas de contrastes térmicos e impermeabilização do solo (LOMBARDO, 1985).
Em Florianópolis a urbanização teve início na década de 50, mas, só em 1973 a população urbana se igualou à rural. Neste momento Florianópolis tornou-se o município mais urbano de sua região. Este crescimento foi acelerado pela instalação de órgãos governamentais estaduais e federais e por uma extensa rede de serviços, refletindo-se numa nítida expansão do setor imobiliário. Em meados da década de 1970 teve início uma acelerada ocupação vertical no centro histórico e a partir da década de 1980 ocorreu a disseminação das funções centrais para demais áreas da região (PELUSO JUNIOR, 1991). Atualmente esta expansão atinge toda a região, principalmente os balneários, em função do incremento governamental às atividades de turismo (MENDONÇA, 2002).

Na região conturbada de Florianópolis o crescimento da população levou à ocupação de áreas de risco, planícies costeiras marinhas e aluviais, sujeitas às inundações e encostas íngremes, propícias aos escorregamentos (Figs. 13 e 14). A expansão 


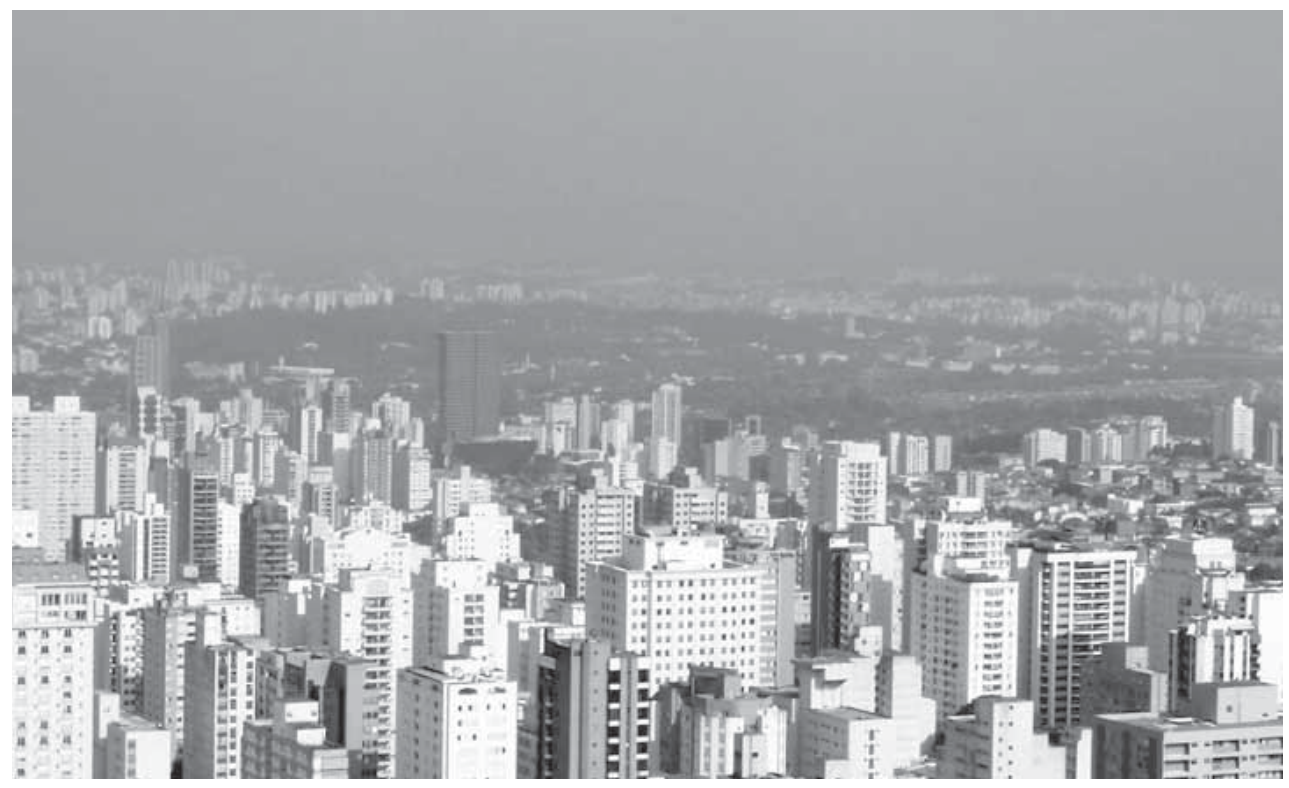

Figura 11 - Vista da área central de São Paulo em dia de inversão térmica. A atmosfera acinzentada sobre a cidade, ao fundo, denuncia uma forte concentração de poluentes. Fonte: http://www. skyscrapercity.com/showthread.php?t=349003.

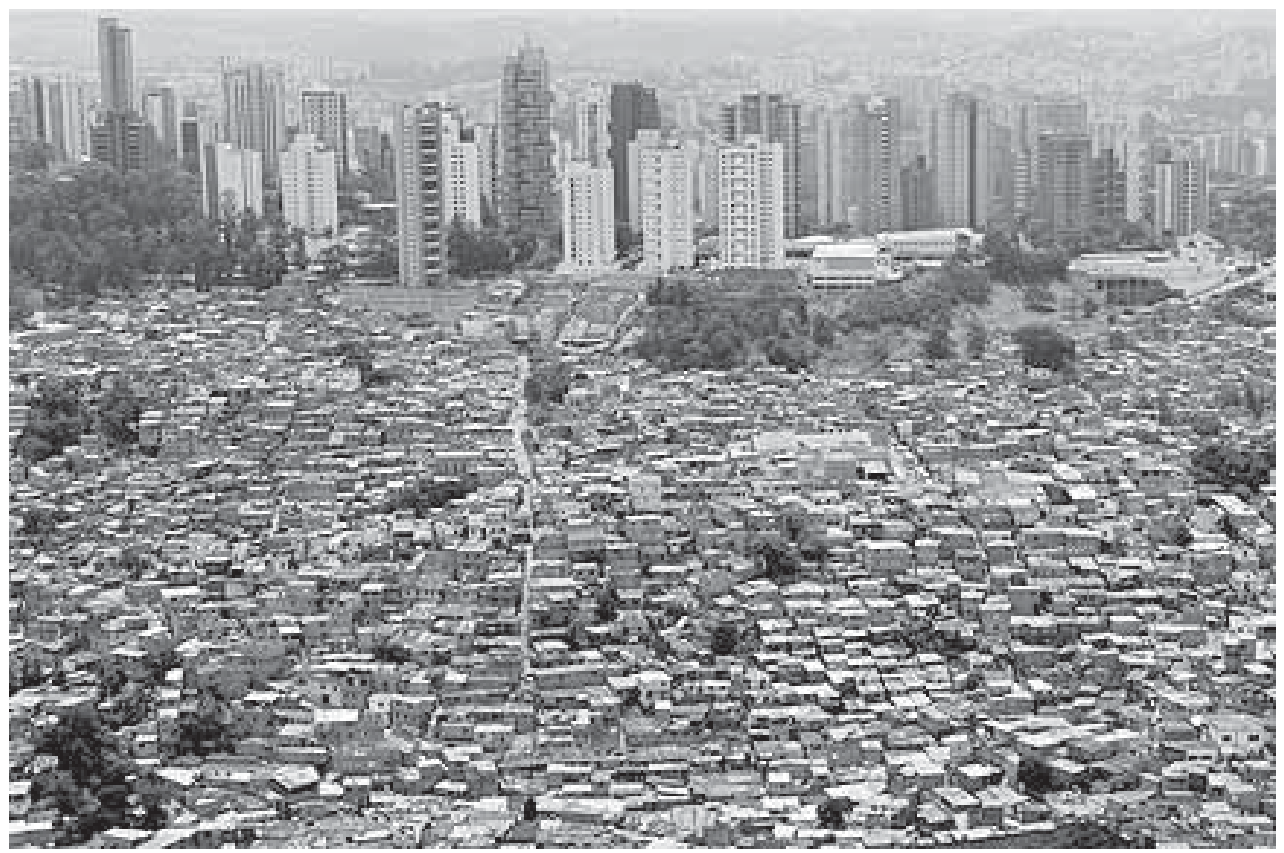

Figura 12 - Vista da cidade de São Paulo e seus contrastes. Edifícios altos e modernos ao fundo e a favela em primeiro plano. Fonte: http://www.google.com.br/images. 


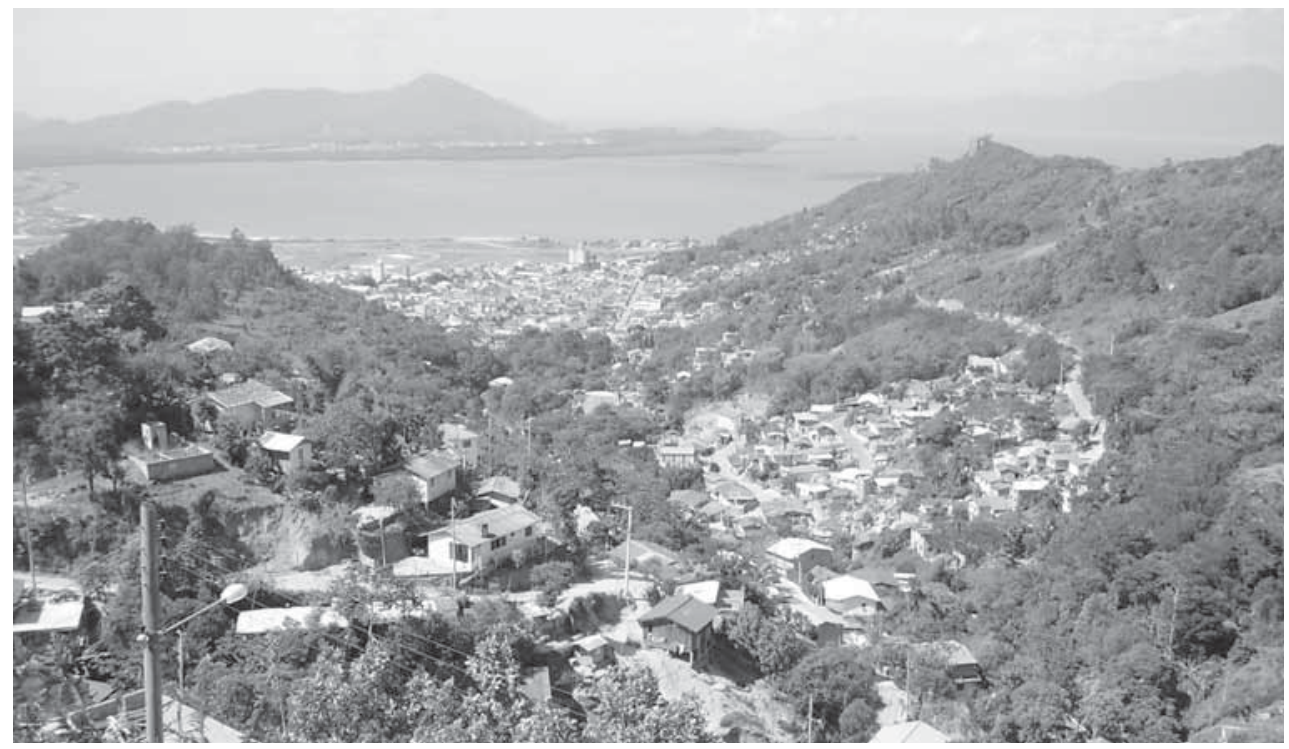

Figura 13 - Vista da ocupação das encostas em Florianópolis. Foto do alto da Caieira do Saco dos Limões feita por Mario Beerli em 2008.

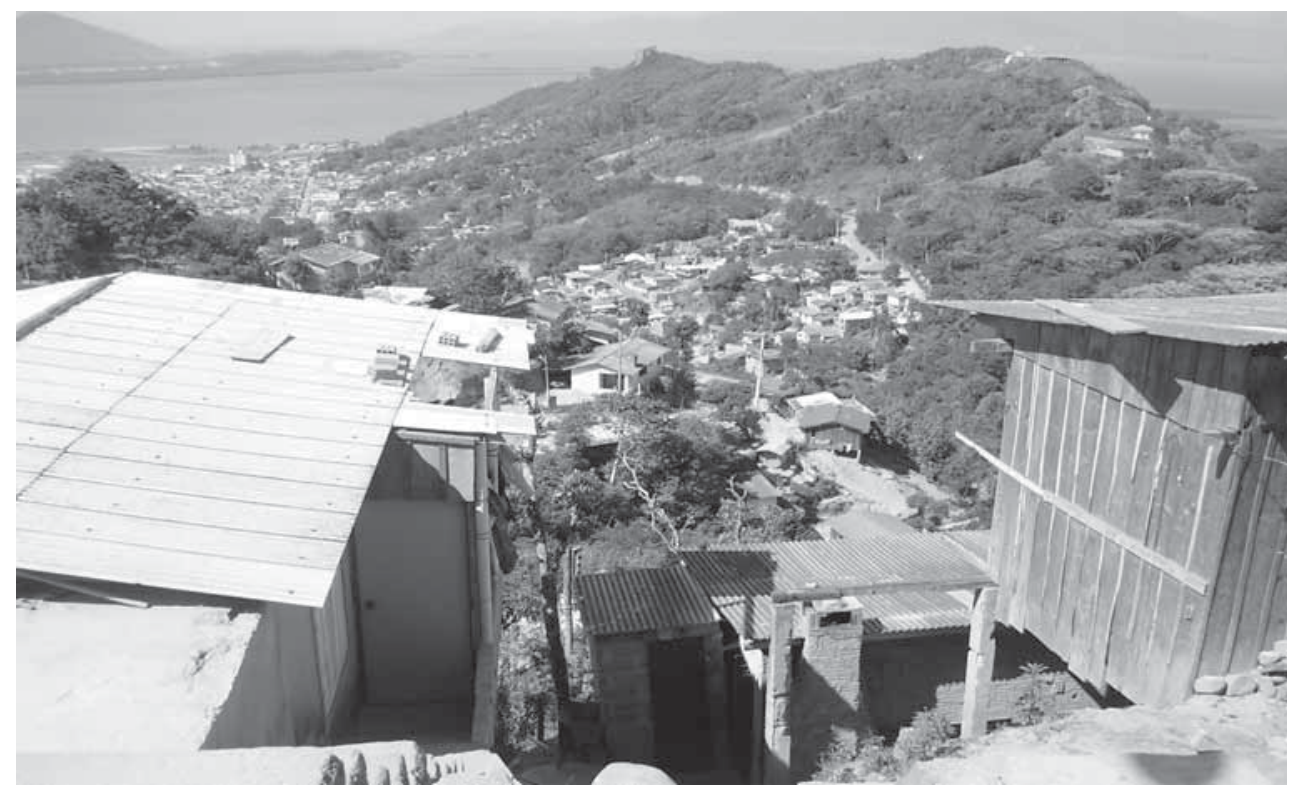

Figura 14 - Detalhe da precariedade da edificação em áreas declivosas suscetíveis à erosão. Foto do alto da Caieira do Saco dos Limões feita por Mario Beerli em 2008.

urbana ocorre em substituição às áreas anteriormente ocupadas pela agricultura. Esta última já havia substituído a exuberante vegetação natural, que hoje se encontra em fase de regeneração pela vegetação secundária rala. A vegetação secundária nos seus estágios iniciais não possibilita uma eficaz proteção ao solo e infiltração da água plu- 
vial, favorecendo o escoamento superficial concentrado e os deslizamentos na encosta. Os leitos dos rios que percorrem as áreas urbanizadas tem sido retilinizados ou canalizados por tubulações subdimensionadas e com entulhos, que dificultam a vazão normal da água junto à foz, ocasionando transbordamento e solapamento das margens (HERRMANN, 2001).

\section{DESASTRES NATURAIS DA URBANI- ZAÇÃO NOS SÉCULO XX E XXI}

BRANDÃO (2001) apresenta um inventário das inundações catastróficas ocorridas no Rio de Janeiro, demonstrando um aumento na frequência de ocorrência: uma no século XVII, duas no século XVIII, 14 no século XIX e 33 no século XX até 1996. A preocupação com as inundações faz parte da historia da cidade e há obras literárias que relatam tempestades que atingiram severamente a cidade em abril de 1756 e fevereiro de 1811. Nos primeiros 40 anos do século

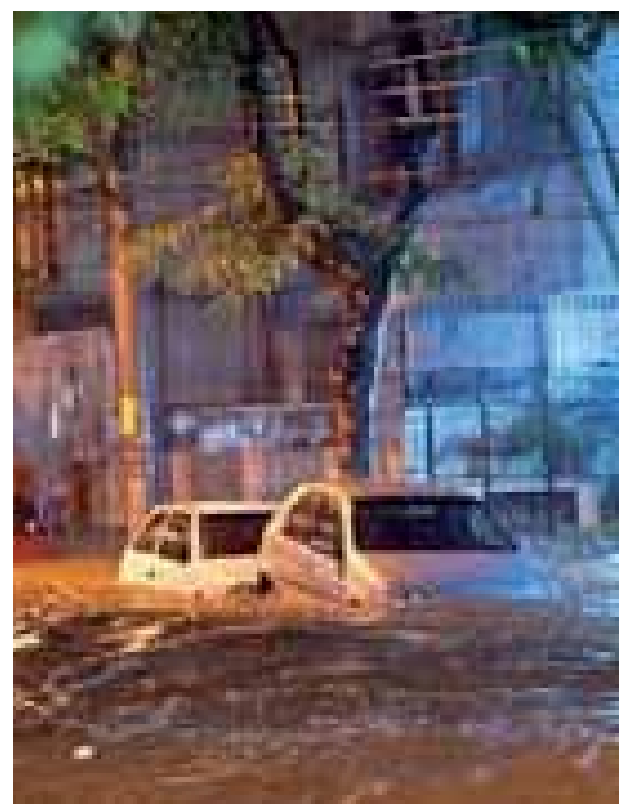

XX foram registradas sete inundações com grandes impactos; de 1940 a 1980, foram registrados 12 e de 1980 a 1996, em menos de 20 anos, foram registrados 14 . A autora constatou uma periodicidade de uma inundação de grande impacto por década: 196667; 1988 e 1996. Pode-se agregar agora a de abril de 2010, com os deslizamentos que causaram mortes no Morro do Bumba.

BRANDÃO (2001) relata os prejuízos causados pelo episódio pluvial que atingiu o Rio de Janeiro entre 19 e 22 de fevereiro de 1988, que causou deslizamentos generalizados nas encostas, inundações de grandes proporções em inúmeros bairros, desabamento de casas e edifícios, além de 277 mortos e mais de 12 mil desabrigados. A referida autora avalia que os eventos pluviais concentrados e seus impactos, após a década de 60, especialmente os que ocorrem de dezembro a março, estão entre os mais importantes na diversidade de problemas ambientais do Rio de Janeiro. Apesar desta constatação enfatiza que a variabilidade cli-

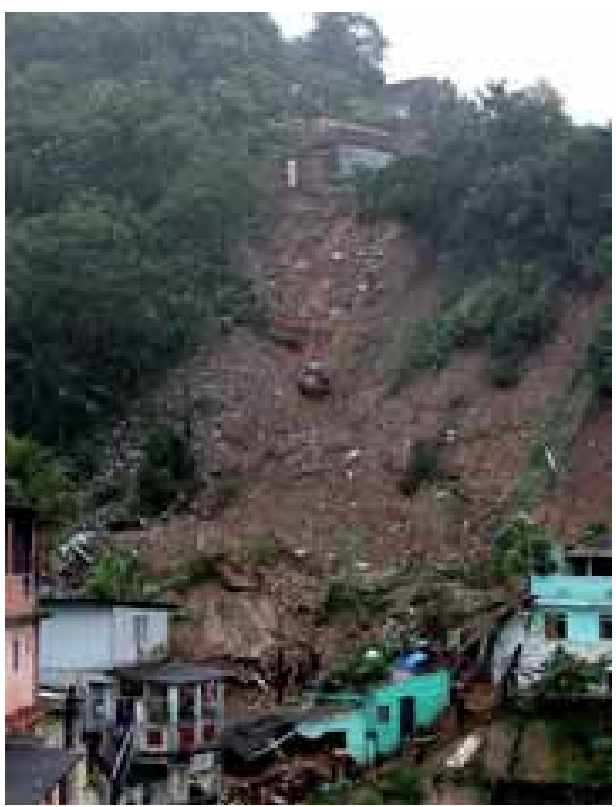

Figura 15 - Inundação e deslizamento no Rio de Janeiro após o temporal em abril de 2010. Fonte: http://guiadicas.net/fotos-da-enchente-no-rio-de-janeiro. 
mática expressa pelos desvios pluviométricos, tanto positivos como negativos, é uma característica do clima da cidade. Ressalta que as chuvas intensas têm merecido maior atenção dos pesquisadores em função de sua frequencia e repercussões socioeconômicas (Fig. 15), porém periodos de grandes estiagens também causaram transtornos à população do Rio de Janeiro.

ALVES FILHO (2001) refere que inundações também fazem parte da história de São Paulo e cita uma ocorrida em 1897 que causou grandes transtornos à população. Entretanto, adverte que os registros de inundações periódicas e de grande intensidade só passaram a ocorrer quase cem anos depois.

Em janeiro de 1947, as chuvas acumularam 481,4 milímetros provocando problemas similares aos atuais, mas em escala menor, pois a cidade tinha 2,2 milhões de habitantes, as ruas eram de terra, a planície de inundação e lagoas pluviais às margens do Tietê não estavam ocupadas, facilitando o escoamento e drenagem. Assim em poucas horas a cidade voltava ao normal (SOUZA, fev.2010).

A diminuição do tempo de recorrência das inundações em São Paulo decorre da expansão espacial da metrópole que se deu em progressão geométrica, nas planícies de inundação, devido à impermeabilização dos solos e importação de água de outras bacias (ALVES FILHO, 2001). O referido autor identificou 40 episódios de inundações no período de 1979 a 1992, porém sua análise se baseou em onze episódios pluviais intensos, ocorridos no decênio 1982-1991, em função do impacto que tiveram sobre a Região Metropolitana de São Paulo.

ALVES FILHO (2001) analisando dados desde a década de 1930 constatou um incremento da precipitação de mais de $200 \mathrm{~mm}$ anuais desde aquela época até o início dos anos 90. Os totais acima da média normal ocorreram especialmente no decênio ana- lisado, em virtude de episódios de chuvas concentradas. Desse incremento na quantidade de água pouco pode ser aproveitado, pois a impermeabilização urbana dificulta a infiltração enquanto o escoamento a contamina pela sujeira difusa da cidade e pelo contato com rios e córregos poluídos. A influência urbana no incremento é sugerida por um mapeamento dos episódios, cujas isolinhas de maior pluviosidade envolvem quase sempre a mancha urbana, sendo que os episódios ocorrem preferencialmente no meio da semana (terças e quartas-feiras). Além disso, a resposta entre o início da chuva e a ocorrência da inundação pode não exceder, em casos extremos, a meia hora. Nos episódios analisados pelo referido autor, observa-se que os totais em 24 horas, em algum ponto da mancha urbana, foram próximos ou superiores a $100 \mathrm{~mm}$. $\mathrm{O}$ rio Tietê foi identificado como o maior causador das inundações e desorganização urbana. Sua bacia hidrográfica capta as precipitações que ocorrem com maior intensidade na área que engloba a capital e que coincide com a planície de inundação onde o Tietê mais extravasa, atingindo seus tributários. As vazões extremas são atribuidas por alguns ao barramento do Tietê em São Paulo que o transformou em um lago e por outros aos problemas na operacionalização das barragens. Porém o autor enfatiza o papel da impermeabilização, do assoreamento e da canalização que aumenta a velocidade dos rios reduzindo o tempo de recorrência e aumentando o impacto sobre o Vale e planície de inundação do Tietê (ALVES FILHO, 2001).

ALVES FILHO (2001) destaca que as grandes inundações estão associadas a episódios de chuva intensa, geralmente de curta duração, enquanto os deslizamentos de encostas ocorrem quando as chuvas perduram por vários dias e são seguidas de uma descarga pluvial mais intensa, como o mesmo observou nos episódios de junho de 1983 e julho de 1989. Na borda do Planalto Paulistano junto a Serra do Mar, episódios pluviais com registros acima de $240 \mathrm{~mm} /$ dia tive- 
ram a influência da circulação marítima e do efeito orográfico, inundando as áreas de baixa declividade a jusante. Isso é notável porque no interior da bacia sedimentar os valores nunca excedem $130 \mathrm{~mm} /$ dia. Já no rebordo do cristalino, o efeito orográfico permitiu valores diários acima de $190 \mathrm{~mm} /$ dia. As ZCAS são os sistemas que atuam na primavera e verão favorecendo as inundações, embora tenham sido observados episódios fora desse padrão. O fenômeno El Niño, mesmo nos episódios mais brandos, leva a escoamentos mais meridionais, que bloqueiam as baixas migratórias que se tornam estacionárias por algum tempo, ocasionando um rompimento do padrão zonal e propagando situações de chuvas intensas (ALVES FILHO, 2001).

Para ALVES FILHO (2001) a crise econômica dos anos 80 e 90, com o aumento do desemprego e diminuição da renda, intensificou os problemas de moradia, agravando as condições ambientais da população. No caso de São Paulo a mancha urbana contínua foi duplicada pela expansão da periferia que abrange as áreas mais distantes e precárias em termos de infraestrutura básica e de serviços. Esta expansão causou assoreamento dos corpos d'água (córregos, rios e represas), lançamento indiscriminado de objetos e restos de construção nos rios e ribeirões, ampliação de favelas em áreas do leito maior dos rios, além de outras edificações ao longo dos rios e ocupação de terrenos de alta declividade, levando à impermeabilização crescente. Tudo isto explicaria em parte o aumento progressivo dos pontos de inundações (ALVES FILHO, 2001).

Quase 20 anos após o último evento estudado por ALVES FILHO (2001), período em que as inundações foram recorrentes durante os verões, em 2010, desde os primeiros dias do ano, a cidade de São Paulo, foi atingida pelo mais catastrófico de todos os episódios. Nos primeiros quarenta dias do ano, os 11 milhões de habitantes conviveram diariamente com tempestades que duraram em torno de duas horas e causaram congestionamentos no trânsito, alagamentos e falta de eletricidade nos bairros; des-

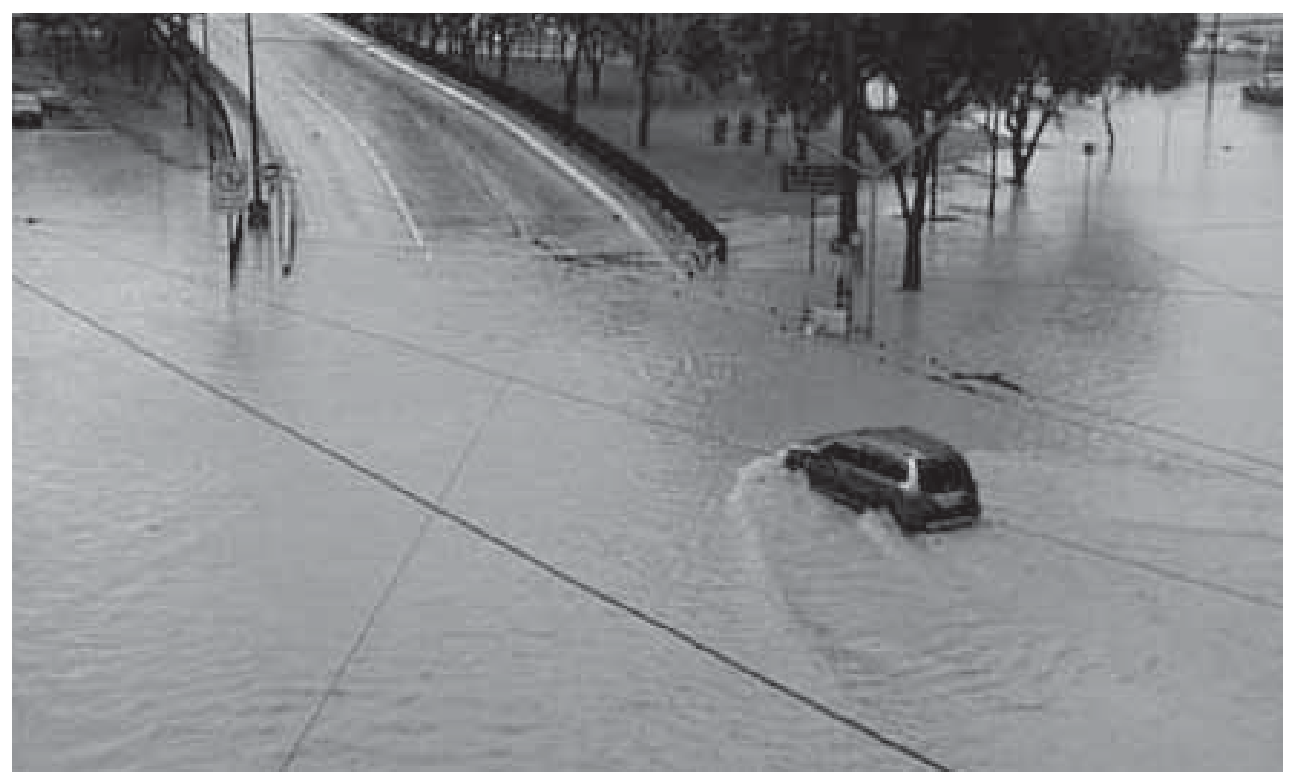

Figura 16 - Área da Grande São Paulo alagada após temporal no dia $1^{\circ}$ de fevereiro de 2010 (Luciano Vicioni/AE). Fonte: http://veja.abril.com.br/noticia/brasil/chuvas-sp-surpreendem-pelafrequencia. 


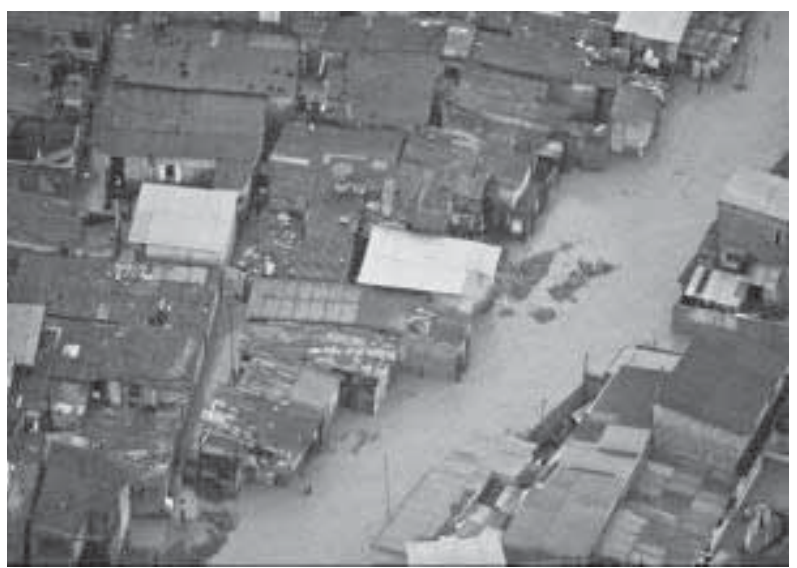

Figura 17 - Bairros atingidos na periferia de São Paulo pelas inundações.

Fonte: http://zenello.wordpress.com/2010/01/25/sao-paulo-nao-e-hora-de-crucificar.

moronamento de casa e queda de árvores levando à morte 14 pessoas (Figs. 16 e 17). No entanto, em 40 dias, choveu 480,5 mm, quase o dobro da média histórica de janeiro $(258 \mathrm{~mm})$ (SOUZA, fev.2010), porém menos do que o dobro do que choveu em 24 e 48 horas em janeiro 1983 e 1984, respectivamente, como relata ALVES FILHO (2001). Assim, seja intensa e concentrada ou distribuida durante um período maior, São Paulo, situada numa região tropical, já não comporta a ocorrência da precipitação que é inerente a sua posição climática.

SOUZA (fev. 2010) após consultar vários especialistas $^{2}$ apresenta uma análise desse último evento diário de precipitações. Todos os anos precipitações intensas se repetem por vários dias pela atuação das ZCAS. Neste ano, este sistema meteorológico foi intensificado pela combinação com o fenômeno El Niño, que se caracterizou pelo aumento da Temperatura da Superfície do Mar (TSM) em $2,0^{\circ} \mathrm{C}$ acima da média no Pacífico Equatorial. No Oceano Atlântico no Caribe a TSM também esteve $1,0^{\circ} \mathrm{C}$ acima da média. $\mathrm{O}$ aumento da temperatura em ambos os oceanos contribuiu para o aumento

2 Luiz Cavalcanti e Marcelo Schneider do Instituto Nacional de Meteorologia (INMET), Carlos Nobre do Instituto Nacional de Pesquisas Espaciais (INPE) e André Madeira da Empresa Climatempo. da umidade responsável pela formação das zonas de convergência que se deslocam no verão em direção ao Atlântico Sul. Este por sua vez também esteve com temperaturas $1,5^{\circ} \mathrm{C}$ acima da média na porção próxima à costa do Sudeste brasileiro, o que torna a brisa marinha que chega ao planalto paulista, onde se localiza a capital, mais úmida e favorável a formação de fortes pancadas de chuva no fim da tarde. Somou-se a estes sistemas atmosféricos o calor produzido pela cidade de São Paulo. Em janeiro a temperatura média foi de $29^{\circ} \mathrm{C}$, mais altas do que a das última seis décadas, pois a normal para este mês é $27,6^{\circ} \mathrm{C}$ (SOUZA, fev.2010). Assim a própria cidade, com seu clima urbano, exerceu um papel de centro de baixa pressão, atraindo para seu sítio o ar úmido produzido em todo país e oceanos no verão tropical do Hemisfério Sul.

O total de precipitação registrado em janeiro de 2010 não foi mais excepcional do que aquele de 1947. Entretanto, por influência do El Niño também choveu acima da média em 2009: em julho o total foi de $179,7 \mathrm{~mm}$ para uma normal de 42,8; em agosto 102, $8 \mathrm{~mm}$ para uma média de $39,1 \mathrm{~mm}$, além de totais acima do normal na primavera. Assim, em janeiro de 2010 houve também uma combinação do solo úmido com uma impermeabilização de $40 \%$ da mancha urbana (SOUZA, fev.2010), e, por conseguinte uma grande 
disponibilidade de água nos rios e reservatórios para evaporação e inundações.

Com chuvas recorrentes e intensas e catástrofes registradas nas décadas de 50, 60 e 70, a cidade continuou se expandindo, eliminando a vegetação e reduzindo as áreas de infiltração. Com o crescimento urbano córregos e rios foram canalizados e transformados em galerias pluviais no subsolo da cidade, dando lugar às grandes avenidas para escoamento do tráfego. Das galerias subterrâneas, de onde deságuam os bueiros, as águas das chuvas vão para galerias maiores e daí são despejadas no Rio Tietê. Assim os alagamentos ocorrem por sobrecarga das galerias ou por transbordamento dos rios. Entre as medidas contra as inundações foram feitos grandes reservatórios subterrâneos para receber as águas e retardar sua chegada aos rios. Porém os reservatórios não têm se demonstrado suficientes. No entanto os governantes nada têm feito para evitar a ocupação do leito maior do rio. Alguns bairros situados às margens do rio Tietê são cronicamente inundados e no mês de janeiro de 2010 permaneceram dois meses sob as águas. A resposta a episódios recorrentes no mesmo período também não é eficiente e os especialistas calculam que em um único dia as inundações causem um prejuízo de 95 milhões de reais só com os congestionamentos no trânsito. Estes são, na opinião do Engenheiro Aloysio Canholi, responsáveis por $80 \%$ das perdas, por imobilização de motoristas, mercadorias e bens, enquanto os outros $20 \%$ estão relacionados com perdas materiais e desvalorização dos imóveis em áreas de inundação (SOUZA, fev.2010).

Na Região Conurbada de Florianópolis os episódios pluviais intensos estiveram associados tanto às variações da circulação atmosférica na escala global, fenômeno El Niño Oscilação Sul (ENSO), quanto à dinâmica atmosférica na escala regional e até local, principalmente em função do relevo e da maritimidade. Tais fatores em associação com os sistemas atmosféricos regionais intensificam os episódios pluviais, frontais e convectivos. As inundações graduais e bruscas, desencadeadoras de escorregamentos, constituem os mais frequentes desastres responsáveis por desalojados, desabrigados, mortos e por significativos impactos sócio-econômicos.

Os desastres aqui caracterizados foram levantados por Herrmann e colaboradores $(1999,2001,2006)$ a partir de consultas aos Relatórios de Avaliação de Danos (AVADAN) da Diretoria Estadual de Defesa Civil de Santa Catarina. Embora outros eventos possam ter causado inundação, os aqui analisados foram reconhecidos e registrados oficialmente pelo poder público, classificados como Calamidade pública e Situação de Emergência. Calamidade Pública significa situação anormal, provocada por desastres naturais causando sérios danos à comunidade afetada e a vida de seus integrantes. Situação de Emergência implica que os danos causados são superáveis, suportáveis pela comunidade, que, apesar de afetada, rapidamente pode retomar a normalidade cotidiana. O reconhecimento de um destes estados garante auxílio financeiro governamental para os municípios afetados.

No período 1980 a 2008 registraram-se oito eventos El Nino e seis eventos La Nina ambos intercalados por periodos de neutralidade, ou seja, de temperaturas da superfície do mar (TSM) no Pacífico Equatorial dentro da média climatológica. Os eventos El Nino ocorridos em 8283; 91-92 e 97-98 foram considerados os de mais forte intensidade. Os anos de La Niña forte foram 88-89 e 2007-2008. De 1998 a 2001 foram registrados dois periodos de La Niña moderado.

Do total de 53 eventos de inundações, 22 foram registrados em anos de El Nino, $13 \mathrm{em}$ anos de La Nina e $18 \mathrm{em}$ anos de neutralidade. Nos eventos mais catastróficos, com desalojados, desabri- 
gados e mortos foi decretada situação de emergência ou de calamidade pública.

Em 1991 a Rodovia BR 101 esteve paralisada por vários dias no trecho que percorre a região conturbada de Florianópolis. Neste evento ocorrido em novembro, pela associação entre um sistema frontal e uma ciclogênese, registrou-se precipitação de 404,8 $\mathrm{mm}$ em 24 horas, 14.545 desabrigados e 10 mortos, devido à inundação e deslizamento. Em fevereiro de 1994 foi registrada inundação (227,4 mm em 4 horas) e escorregamentos na região, com 907 desabrigados e três mortos. Estes dois eventos estiveram associados a anos de El Niño.

Em eventos La Niña também foram registradas inundações calamitosas: em dezembro de 1995 a ocorrência de um sistema frontal e um vórtice ciclônico causou dois periodos de precipitação que totalizaram $411,9 \mathrm{~mm}$ e 273,14 $\mathrm{mm}$, deixando 7500 desabrigados e um morto. Em março de 1996, novamente um sistema frontal, um vórtice ciclônico e um cavado, causaram mais de 300 $\mathrm{mm}$ de precipitação pluvial, inundação, deixando 905 desabrigados. Em 1988 foi registra estiagem em julho.

No atual período de ODP em sua fase fria só não foram registradas inundações em 2000, 2002 e 2005. Situações de emergência foram registradas em 2003, 2004 e 2008 em situações de neutralidade, El Niño fraco e La Niña forte, respectivamente. Em 2003 registrou-se estiagem em julho, em janeiro de 2004 uma inundação que deixou 1500 afetados, 70 desalojados e prejuizos econômicos. No final de janeiro e início de fevereiro de 2008, outra inundação, com precipitações que totalizaram 136, $9 \mathrm{~mm}$, deixou 21.160 afetados e 1270 desabrigados.

Considerando-se as quatro estações dentro do mesmo ano, admite-se que o verão inicia em janeiro; o outono em abril; o inverno em julho e a primavera em outubro. Dentro desta classificação observou-se que, no período de 1980-2008, 55\% das inundações ocorreram no verão, $23 \%$ na primavera, $8 \%$ no outono e $14 \%$ no inverno. Estes percentuais refletem a frequência de atuação dos sistemas atmosféricos, com maior ocorrência de convecção no verão, associada à maritmidade e orografia; bloqueios atmosféricos típicos do outono, que caracterizam periodos de estiagem; intensificação das frentes no inverno, com a ocorrência de frentes estacionárias nos anos de El Nino e atuação dos CCMs na primavera, quando também as frentes em deslocamento pelo Atlântico, aumentam sua frequência em relação às demais estações (OLIVEIRA, 1986; RODRIGUES, 2003). Os eventos mais catastróficos, independentes dos fenômenos de escala global, ocorreram principalmente no verão e primavera. As inundações ocorreram na primavera mesmo em periodos de La Nina como 83, 84 e 95, apesar de a primavera ser considerada a estação que registra menores totais de precipitação em anos de La Niña. Nos anos de El Nino poucas inundações ocorreram na primavera do ano de início do evento e no outono e inverno do segundo ano; elas ocorreram principalmente no verão. As inundações também ocorrem quando a maré alta se associa aos totais pluviométricos excepcionais, dificultando a vazão.

Entretanto, não é só o clima e sua variabilidade que determinam a ocorrência das inundações e suas consequências em Florianópolis. Como qualquer outra cidade e principalmente por suas paisagens de grande valor turístico, a capital do estado e sua região se expandem a partir de diretrizes ditadas pela valorização imobiliária da terra sem a consideração das vulnerabilidades de natureza física, sociais e a importância dos serviços ambientais. O aumento de situações de emergência e calamidade pública nas últimas décadas está relacionado ao crescimento da população, 

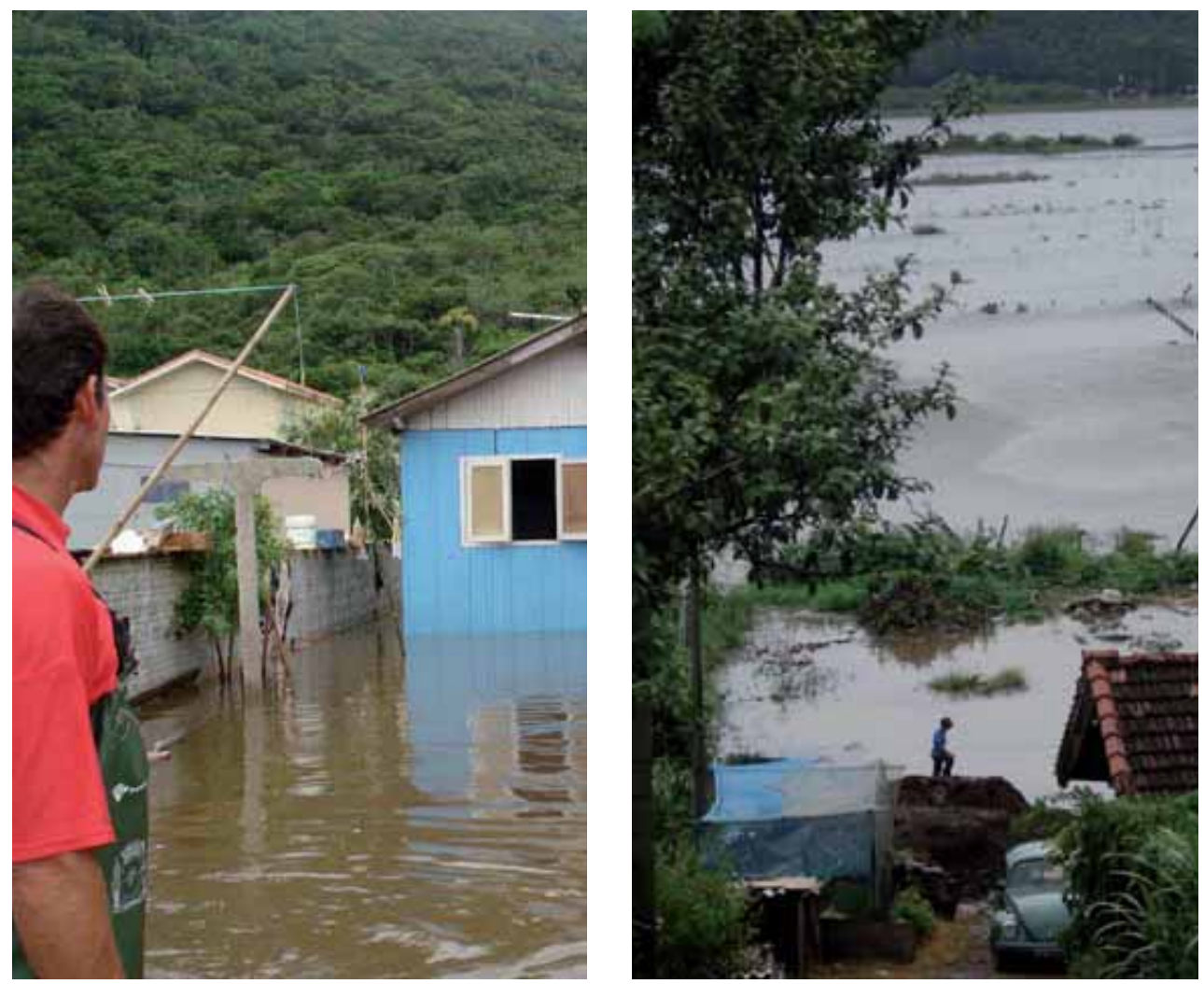

Figura 18 - Inundação no Pântano do Sul, em Florianópolis, no final de janeiro de 2008. Na primeira foto casas inundadas no Bairro. Na segunda, inundação em lotes parcelados para a venda. Fotos de Rosemy da Silva Nascimento.

cuja concentração nas cidades leva à ocupação de áreas de risco, planícies costeiras marinhas e aluviais, sujeitas às inundações e encostas íngremes, propícias aos escorregamentos. A ocupação urbana avança edificando sobre áreas agrícolas e de regeneração da vegetação, retilinizando e canalizando rios e córregos. A impermeabilização das superfícies impossibilita uma eficaz proteção do solo e infiltração da água pluvial, favorecendo o escoamento superficial concentrado que causa as inundações nas planícies e os escorregamentos na encosta (Fig. 18).

\section{A VULNERABILIDADE URBANA DIANTE DA VARIABILIDADE DO CLIMA}

Não resta dúvida do papel do clima do Centro Sul brasileiro no desencadeamento de precipitações torrenciais e concentradas. $\mathrm{Na}$ mancha urbana das três cidades e suas regiões têm sido registradas inundações excepcionais, com precipitações cujos totais são superiores a $100 \mathrm{~mm}$ em 24 horas. Esses eventos se concentram de dezembro a março pelo aumento da convecção continental que potencializa a evaporação dos solos e dos corpos d'água; mas podem ocorrer em qualquer estação do ano. Em anos de El Niño podem ser mais generalizados no território, atingindo várias bacias hidrográficas em cada um dos estados em que se localizam essas cidades e principalmente nos estados do sul do Brasil. 
O relevo do Centro Sul do Brasil com planaltos, serras e encostas íngremes, amplas planícies aluviais e costeiras, em associação com as chuvas concentradas, também constitui fator físico-natural de vulnerabilidade. Os eventos pluviais intensos, entretanto, não expressam uma mudança na atuação dos sistemas atmosféricos. Eles têm sido relatados desde a colonização de nosso país por navegantes, cientistas e clérigos. Estão também registrados em romances e em arquivos públicos. Entretanto, atualmente se constituem em um dos mais importantes problemas ambientais urbanos, devido à repercussão sócio-econômica que têm (BRANDÃO, 2001). Reconhece-se também que a vulnerabilidade dos fatores físicos para a ocorrência de episódios pluviais intensos e seus impactos, tem sido intensificada pelo processo acelerado e concentrado da urbanização.

Os locais atingidos por esses episódios, seja em São Paulo, no Rio de Janeiro ou Florianópolis, normalmente se constituem em áreas de risco, como encostas íngremes e degradadas e planícies de inundação; onde a densidade de construções e demográfica é elevada; as áreas com cobertura vegetal são raras, onde vive a população mais pobre, carente de infra-estrutura; seja em favelas ou em conjuntos habitacionais construidos e financiados pelo Governo; seja em loteamentos irregulares, destinados a classes sociais com mais recursos. Em São Paulo e Rio de Janeiro coincidem também com as áreas de pior qualidade de ar. As inundações paralisam principalmente os transportes rodoviários, causam deslizamentos de encostas, desabamentos de edificações, deixam desabrigados, mortos e milhares de afetados.

\section{CONSIDERAÇÕES FINAIS}

Assim, em primeiro lugar é necessário reconhecer, como já demonstrou PETTERSSEN (1968, citado por VIANELLO \& ALVES, 1991) que vivemos em uma das regiões do planeta mais propensas as tem- pestades severas, com uma frequência superior a $20 \%$ das ocorrências mundiais. Em segundo, continuar realizando pesquisas para determinar os ritmos e impactos das variabilidades climáticas a que estão submetidas nossas regiões e cidades. A escala local dos climas, embora subordinada aos mecanismos atmosféricos globais, pode apresentar uma expressão diversa, não apenas em função de fatores geográficos, como relevo e altitude, mas também pelo uso e ocupação da terra.

Faz-se necessário também reavaliar a crença na ciência e na tecnologia como domesticadoras na natureza. Saint-Hilaire (1816-1821) descreve a planície do Tietê no século XIX inundada por dois a três meses. Na época as inundações favoreciam a agricultura (SANT' ANNA NETO, 2004). Quase 200 anos depois, após grandes progressos técnico-científicos, as inundações paralisam uma das maiores cidades do mundo, principalmente às margens do Rio Tietê. Todos os melhores conhecimentos em obras de engenharia e muito recurso econômico foram disponibilizados para canalizar os córregos e rios e transformá-los em galerias; reservatórios a céu aberto foram construídos para acumular as precipitações e os subterrâneos para absorver o escoamento pluvial. Entretanto todo esse sistema de defesa não é capaz de evitar as rotineiras inundações de verão, pois as chuvas sem possibilidade de infiltrarem-se, sobrecarregam as galerias que levam ao transbordamento dos rios. Mas o leito maior do rio, que atravessa a cidade, subordinado aos interesses econômicos, segue sendo ocupado e bairros situados às suas margens são cronicamente inundados.

Nossas cidades caracterizadas pelo adensamento de construções, pela eliminação da vegetação e impermeabilização dos solos, tornaram-se, como admitem especialistas em centros de baixa pressão capazes de intensificar as precipitações sobre elas. Torna-se cada dia mais claro que devemos adaptar nossas cidades a primeira natureza, 
pois a segunda natureza, criada pela sociedade contemporânea, não está se adaptando à qualidade de vida almejada pela maior parte da população.

\section{REFERÊNCIA BIBLIOGRÁFICA}

AGUIAR, D; MENDONÇA, M., 2004. Climatologia das geadas em Santa Catarina. In: SIMPÓSIO BRASILEIRO DE DESASTRES NATURAIS, 1. Florianópolis. Anais... Florianópolis: $762-773$ (CD-ROM).

ALVES FILHO, A.P. 2001. As Enchentes. . In: TARIFA, José R. \& AZEVEDO, Tarik R. de (orgs). Os Climas na Cidade de São Paulo: teoria e prática. São Paulo: Pró-Reitoria de Cultura e Extensão. Universidade de São Paulo:Laboratório de Climatologia. Faculdade de Filosofia, Letras e Ciências Humanas: 94-111.

ALVES, J. J. A., 2007. Geoecologia da Caatinga do Semi-Árido do Nordeste Brasileiro. Climatologia e Estudos da paisagem. Rio Claro, v.2, n.1, jan./jun: 58-71. Disponível em: www.periodicos.rc.biblioteca. unesp.br/index.php/climatologia/article/.../667. Acessos Em: set. 2010.

AYOADE, J. O., 1986. Introdução a climatologia para os trópicos. Tradução de Maria Juraci Zani dos Santos; revisão de Suely Bastos. São Paulo: DIFEL: 332 .

BRANDÃO, A. M. de P. M. 2001. Clima Urbano e Enchentes na Cidade do Rio de Janeiro. In: GUERRA, Antônio J. T. \& CUNHA, Sandra B. da (orgs). Impactos Ambientais urbanos no Brasil. Rio de Janeiro: Bertrand Brasil. p. 49 - 109.

CPTEC/INPE. 2010. El Niño e La Niña. Disponível em: http://enos.cptec.inpe.br. Acessos Em: set. 2010.
CIRAM/EPAGRI. Fenômeno El Niño/ La Niña. Disponível em: http://ciram. epagri.sc.gov.br/portal/website/index. jsp?url=jsp/materialDidatico/elNino. jsp\&tipo=materialDidatico. Acesso em: set. 2010.

CIRAM/EPAGRI. Boletim de Monitoramento Climático para Santa Catarina de maio de 99. Disponível em: http//200.18.5.1/. Acesso em: 07 maio 1999a.

CIRAM/EPAGRI. Fenômeno El Niño. Disponível em: http://.200.18.5.1/nino/ index.html. Acesso em: 08 jun. 1999b.

CIRAM/EPAGRI. Fenômeno La Niña. Disponível em: http://.200.18.5.1/nina/ index.html. Acesso em: 08 jun. 1999c.

CLIMANÁLISE. Boletim de Monitoramento e Análise Climática. Vários números. Disponível em: www.cptec.inpe.br/ products/climanalise. Acessos em: jan/2009 e junho/2010.

CLIMANÁLISE. Especial de 10 anos. Disponível em: http://tucupi.cpetec.inpe. br/ products/climanalise/cliesp10a/jatclim. html. Acesso em 2005, 2009 e 2010.

CIRAM/EPAGRI. Fenômeno El Niño/ La Niña. Disponível em: http://ciram. epagri.sc.gov.br/portal/website/index. jsp?url=jsp/materialDidatico/elNino. jsp\&tipo=materialDidatico. Acesso em: set. 2010.

CHRISTY, J; SPENCER, R. Global Temperature Report 1978-2003, The University of Alabama in Huntsville. Disponível em meteo.lcd.lu/globalwarming/Christy_andSpencer/25years_highlite.pdf, 2003.

ERHART, H. 1966. A teoria bio-resistática e os problemas biogeográficos e paleobiológicos. Not.

Geomorfológica, Ano VI, n. 11: 51-58. 
GRIMM, A. M.; FERRAZ, S. E. T.; GOMES. J., 1998. Precipitation anomalies in southern Brazil associated with El Niño and La Niña events. Journal of Climate, v. 11: 2863-2880.

HARO, Martim A. P. de (org).1996. Ilha de Santa Catarina; relatos de viajantes estrangeiros nos séculos XVIII e XIX. Florianópolis: Editora Lunardelli, Editora da UFSC, 4.ed: 236.

herRMANN, Maria Lúcia de P. (org.). 2005. Atlas de Desastres Naturais do Santa Estado de Santa Catarina, Florianópolis: IOESC: 5-10 (CD e impresso ago 2007), 2006.

HERRMANN, Maria Lúcia de P. (org.).2005. Levantamento dos Desastres Naturais Causados pelas Adversidades Climáticas no Estado de Santa Catarina, período 1980 a 2000. Florianópolis: IOESC, 2001: 89 .

HERRMANN, Maria Lúcia de P. (org.). 2005. Problemas geoambientais na faixa central do litoral catarinense. 1999, Tese (Doutorado em Geografia Física), USP/ FFLCH, São Paulo, 1999.

KAYANO, Mary. T. ANDREOLI, Rita. V. Variabilidade decenal a multidecenal. CAVALCANTI, I. F. de A.; FERREIRA, N. J. ; SILVA, M. G. A. J. da; DIAS, M. A. F. da S. (Orgs.) In: Tempo e Clima no Brasil. São Paulo: Oficina de Textos, 2009: 375-383.

LOMBARDO, Magda A., 1985. Ilha de calor nas metrópoles - o exemplo de São Paulo. HUCITEC, São Paulo: 244.

MANTUA, N.J., S.R. HARE, Y. ZHANG, J.M. WALLACE, and R.C. FRANCIS. A 1997. Pacific interdecadal climate oscillation with impacts on salmon production. Bulletin of the American Meteorological Society. 78: 1069-1079.
MARQUES, Rafael. 2010. Distribuição Espaço-Temporal da Precipitação Pluviométrica e Variabilidade Climática na Bacia Hidrográfica do Rio Tubarão e Complexo Lagunar: 156 . Dissertação (Mestrado em Geografia). Universidade Federal de Santa Catarina, Florianópolis, 2010.

MENDONÇA, Magaly. 2002. A dinâmica têmporo-espacial do clima subtropical na região conurbada de Florianópolis/SC. 2002: 343 Tese (Doutorado em Geografia Física). São Paulo: USP. Faculdade de Filosofia Letras e Ciências Humanas (FFLCH). Departamento de Geografia (DG), (inédita)

MOLION, L. C. B. 2008. Aquecimento Global: Uma Visão Crítica. Revista Brasileira de Climatologia. Presidente Prudente: Associação Brasileira de Climatologia (ABCLIMA), v.3/4 n.3: 7-23.

- Aquecimento Global, El Niños, Manchas Solares, Vulcões e Oscilação Decadal do Pacífico. Disponível em: http:// climanalise.cptec.inpe.br/ rclimanl/revista. Ano 3, no 1, 2006. Acesso em: set. 2010.

MONTEIRO, Maurici. A. \& MENDONÇA, Magaly. 2006. Dinâmica Atmosférica do Estado de Santa Catarina. HERRMANN, Maria Lúcia de P. (org.). Atlas de Desastres Naturais do Santa Estado de Santa Catarina. Florianópolis: IOESC, 2005: 5-10 (CD e impresso ago 2007).

MONTEIRO, Maurici A. A. 2001. Caracterização climática do estado de Santa Catarina: uma abordagem dos principais sistemas atmosféricos que atuam durante o ano. Geosul. Revista do Dep. de Geociências da UFSC, Florianópolis, Editora da UFSC, n.31: 69-78.

NIMER, E. 1979. Climatologia do Brasil. Rio de Janeiro: IBGE: 422 . 
NOBRE, Carlos A.; YOUNG, Andrea F.; SALDIVA, Paulo; MARENGO, José A.; NOBRE, Antônio; ALVES JR., Sinésio; SILVA, Gustavo C. M. da e LOMBARDO, Magda. Vulnerabilidades das Megacidades Brasileiras às Mudanças Climáticas: Região Metropolitana de São Paulo. Disponível em: http://www.inpe.br/noticias/arquivos/pdf/ megacidades.pdf. Acessos em nov.de 2010.

OLIVEIRA, A. S. 1986. Interações entre sistemas frontais na América do Sul e a convecção da Amazônia: 134. Dissertação (Mestrado em Meteorologia) - Instituto Nacional de Pesquisas Espaciais, São José dos Campos.

PELUSO JÚNIOR, V. A. 1991. Estudos de geografia urbana de Santa Catarina. Florianópolis: Ed. da UFSC: Secretaria de Estado da Cultura e o Esporte: 400 .

PETTERSSEN, S. 1968. Introducción a la meteorología. Madri: Espasa-Calpe: 429.

PHILLIPPS,T. Spotless Sun: Blankest years of the last century (www.science.nasa. gov, 2008). Disponível em: http://eternosaprendizes.com/tag/mancha-solar.Acessos em: set. 2010 .

RODRIGUES, M. L. G. 2003. Uma climatologia de frentes frias no litoral de catarinense com dados de reanálise do NCEP: 75. Dissertação (Mestrado em Engenharia Ambiental) - Universidade Federal de Santa Catarina, Florianópolis.

ROSS, J. L. S. 2001. Os Fundamentos da Geografia da Natureza. In: ROSS, Jurandyr L. S. (Org.) Geografia do Brasil. 4ed. São Paulo: Editora da Universidade de São Paulo: 67-207.

SACCO, F. G. 2010. Configurações Atmosféricas em Eventos de Estiagem de 2001 a 2006 na Mesorregião Oeste Catarinense: 109. Dissertação (Mestrado em Geografia). Universidade Federal de Santa Catarina, Florianópolis.
SANT'ANNA NETO, J. L. 2004. História da Climatologia no Brasil- gênese, paradigmas do clima como fenômeno geográfico. Cadernos Geográficos. Florianópolis: Universidade Federal de Santa Catarina. CFH. Departamento de Geociências, n.7, maio: 4, 124.

SILVA DIAS, P.; MARENGO, J. 2002. Águas atmosféricas. In: REBOUÇAS, A. C.; BRAGA JUNIOR, B.; TUNDIZI, J. G (orgs). Águas doces no Brasil - capital ecológico, usos múltiplos, exploração racional e conservação. São Paulo: Escrituras Editora: 65-116.

SOUZA, O. de. 2010. Dilúvio...45 $45^{\circ}$ dia. Veja. São Paulo: Abril, 2151 ed., ano 43, n. 6, 10 fev: 65-69.

SPINELLI, K. 2009. Análise das geadas no município de Caçador (SC) no periodo de 1961-2008: 100. Monografia (Bacharelado em Geografia - Universidade Federal de Santa Catarina, Florianópolis.

SUGUIO, K. 1998. Dicionário de Geologia Sedimentar e áreas afins. Rio de Janeiro: Bertrand Brasil.

VIANELLO, R. L. \& ALVES, A. R. 1991. Meteorologia Aplicações. Viçosa, UFV: 377-446, ilust.

VEYRET, Y. 2007. Os Riscos: o homem como agressor e vítima do meio ambiente. Tradução Dilson Ferreira da Cruz. São Paulo: Contexto: 319.

VITTE, A. C. Breve História da Geomorfologia no Brasil. Disponível em: http:// enhpgii.files.wordpress.com/2009/10/texto_antonio_carlos_vitte.pdf. Acessos em: set. 2010. 